\title{
Unravelling the enigmatic origin of calcitic nanofibres in soils and caves: purely physicochemical or biogenic processes?
}

\author{
S. Bindschedler ${ }^{1, *}$, G. Cailleau ${ }^{1}$, O. Braissant ${ }^{3}$, L. Millière ${ }^{1, * *}$, D. Job ${ }^{2}$, and E. P. Verrecchia ${ }^{1}$ \\ ${ }^{1}$ Institute of Earth Surface Dynamics, University of Lausanne, Geopolis, 1015 Lausanne, Switzerland \\ ${ }^{2}$ Laboratory of Microbiology, Institute of Biology, University of Neuchâtel, Rue Emile Argand 11, 2009, Switzerland \\ ${ }^{3}$ Laboratory of Biomechanics and Biocalorimetry, Biozentrum/Pharmazentrum, University of Basel, Klingelbergstr. 50-70, \\ 4056 Basel, Switzerland \\ * present address: Laboratory of Microbiology, Institute of Biology, University of Neuchâtel, Rue Emile Argand 11, 2009, \\ Switzerland \\ ** present address: Institut für Mineralogie, Universität Münster, Corrensstr. 24, 48149 Münster, Germany
}

Correspondence to: S. Bindschedler (saskia.bindschedler@unine.ch)

Received: 1 December 2013 - Published in Biogeosciences Discuss.: 16 January 2014

Revised: 7 April 2014 - Accepted: 10 April 2014 - Published: 27 May 2014

\begin{abstract}
Calcitic nanofibres are ubiquitous habits of secondary calcium carbonate $\left(\mathrm{CaCO}_{3}\right)$ accumulations observed in calcareous vadose environments. Despite their widespread occurrence, the origin of these nanofeatures remains enigmatic. Three possible mechanisms fuel the debate: (i) purely physicochemical processes, (ii) mineralization of rod-shaped bacteria, and (iii) crystal precipitation on organic templates. Nanofibres can be either mineral (calcitic) or organic in nature. They are very often observed in association with needle fibre calcite (NFC), another typical secondary $\mathrm{CaCO}_{3}$ habit in terrestrial environments. This association has contributed to some confusion between both habits, however they are truly two distinct calcitic features and their recurrent association is likely to be an important fact to help understanding the origin of nanofibres. In this paper the different hypotheses that currently exist to explain the origin of calcitic nanofibres are critically reviewed. In addition to this, a new hypothesis for the origin of nanofibres is proposed based on the fact that current knowledge attributes a fungal origin to NFC. As this feature and nanofibres are recurrently observed together, a possible fungal origin for nanofibres which are associated with NFC is investigated. Sequential enzymatic digestion of the fungal cell wall of selected fungal species demonstrates that the fungal cell wall can be a source of organic nanofibres. The obtained organic nanofibres show a striking morphological resemblance when compared to their natural counterparts, emphasizing a fungal origin for part of the organic
\end{abstract}

nanofibres observed in association with NFC. It is further hypothesized that these organic nanofibres may act as templates for calcite nucleation in a biologically influenced mineralization process, generating calcitic nanofibres. This highlights the possible involvement of fungi in $\mathrm{CaCO}_{3}$ biomineralization processes, a role still poorly documented. Moreover, on a global scale, the organomineralization of organic nanofibres into calcitic nanofibres might be an overlooked process deserving more attention to specify its impact on the biogeochemical cycles of both $\mathrm{Ca}$ and $\mathrm{C}$.

\section{Introduction}

Calcitic nanofibres are features of secondary calcium carbonate $\left(\mathrm{CaCO}_{3}\right)$ deposits commonly observed in various vadose environments (caves - as moonmilk, soils, aqueducts). These features are almost always described in the presence of another typical feature of secondary $\mathrm{CaCO}_{3}$ deposits, needle fibre calcite (NFC), a monocrystalline habit thought to be fungal in origin (Callot et al., 1985a; Phillips and Self, 1987; Verrecchia and Verrecchia, 1994; Cailleau et al., 2009b; Bindschedler et al., 2012). While the biogenic origin of NFC appears to be fairly accepted, the origin of calcitic nanofibres remains enigmatic. Many authors have reported the presence of nanofibres in various continental environments (Klappa, 1979; Phillips and Self, 1987; Jones and Ng, 1988; Jones 
and Khale, 1993; Verrecchia and Verrecchia, 1994; Gradziński et al., 1997, 2012; Loisy et al., 1999; Borsato et al., 2000; Benzerara et al., 2003; Richter et al., 2008; Cailleau et al., 2009a, b; Bindschedler et al., 2010). However, despite this ubiquity, the origin of calcitic nanofibres still remains unclear (Banerjee and Joshi, 2013). Three hypotheses for their formation have been proposed: (i) physicochemical processes (Jones and Ng, 1988; Jones and Khale, 1993; Borsato et al., 2000); (ii) biomineralization of rod-shaped nano-sized bacteria (Phillips and Self, 1987; Verrecchia and Verrecchia, 1994; Loisy et al., 1999; Gradziński et al., 2012); and (iii) nucleation mediated by an organic template (Benzerara et al., 2003; Olszta et al., 2004; Cailleau et al., 2009a).

The recurrent association between nanofibres and NFC is likely to be a significant fact to explain the origin of nanofibres. In particular, these two features are often observed in close physical contact, emphasizing an intimate relationship (Bindschedler et al., 2012). Bindschedler et al. (2010), based on an osmium labelling method, demonstrated that organized meshes of nanofibres (i.e. showing preferential orientations and/or forming larger-scale structures) have an organic signature. As a result, nanofibres observed in natural samples can be either mineral or organic in nature. In the present study, in order to have a clear terminology for each type, the mineral type is referred to as "calcitic nanofibres" and the organic type as "organic nanofibres". When discussing both types indifferently, the term "nanofibres" alone is used. Based on the fact that strong evidence exists to support the fungal origin of NFC, Bindschedler et al. (2010) propose that these organic nanofibres might originate from fibrillar components of fungal origin, such as nanofibrous material of the fungal cell wall (chitin and/or $\beta$-1,3-glucan; Carlile et al., 2001). They further propose that these organic nanofibres, when exposed to fluids saturated towards calcite, can be mineralized and thus become calcitic nanofibres. Soils and caves, where nanofibres and NFC are typically observed, are common fungal habitats (Gobat et al., 2003; Paul, 2007). Therefore, a fungal origin for organic nanofibres is rational. Moreover, other authors have already put forward the hypothesis of an indirect biogenic origin, involving "organic nanofibres coming from a cell wall” (Klappa, 1979; Cailleau et al., 2009a; Bindschedler et al., 2010). Both fungi and plants harbour a cell wall composed partly of fibrous polymers and thus can be a source of organic nanofibres (Carlile et al., 2001; Paul, 2007).

The influence of biological systems on mineral precipitation and crystallization is known as biomineralization, $\mathrm{CaCO}_{3}$ being the most common biomineral in the biosphere (Lowenstam and Weiner, 1989). Different levels of biological influence on mineralization have been defined: (i) tight biological control, (ii) induction by biological activities and (iii) passive biological influence (Dupraz et al., 2009). Biominerals are found in a myriad of different habits, and their recognition as biominerals is often difficult. However, they represent critical indicators of past environmental conditions when observed in fossil records. Therefore, the clear recognition of their nature is of great importance to help understand the processes to which they might be related (Weiner and Dove, 2003; Dupraz et al., 2009). The concomitant presence of nanofibres and NFC in secondary $\mathrm{CaCO}_{3}$ deposits is used as a paleoenvironmental and/or paleoclimatic proxy indicating arid to semiarid climatic conditions (Wright, 1984, 1986; Jones and Ng, 1988; Turner and Makhlouf, 2005; Shankar and Achyuthan, 2007). However, both features are also regularly described from environments with more humid climates (Callot et al., 1985a; Strong et al., 1992; Gradziński et al., 1997; Borsato et al., 2000; Khormali et al., 2006; Cailleau et al., 2009b; Zhou and Chafetz, 2009; Bindschedler et al., 2010, 2012; Millière et al., 2011a, b). Therefore, the clarification of the origin of both calcitic habits is essential to retrieve accurate information regarding the conditions that led to their formation in order to use them properly as a paleoenvironmental and/or paleoclimatic proxy.

In this paper we propose a critical review on the hypotheses for the origin of calcitic nanofibres that are currently accepted. In addition we propose a new original hypothesis based on the fungal origin of NFC. We show that fungal hyphae can be a potential source of organic nanofibres by using a sequential enzymatic digestion of fungal mycelia under controlled conditions. In particular, characteristics such as dimension and tri-dimensional organization patterns of nanofibrous material resulting from an incomplete decay of the fungal cell wall is compared to natural counterparts. Such an approach is intended to mimic the natural microbial decay of soil organic matter as closely as can be achieved under controlled in vitro conditions.

\section{State of the art}

\subsection{Calcitic nanofibres}

Calcitic nanofibres are elongated needle-like, or acicular, habit of low-Mg calcite (Loisy et al., 1999; Borsato et al., 2000). They are frequently observed in association with NFC. This fact, together with their morphological similarity, has sometimes led to a confusion between both habits. Nevertheless, their dimensions, as well as their shape, are different. Nanofibres exhibit an average width of $50-150 \mathrm{~nm}$ and length from 10 up to $10^{4}$ times their width (Table 1). They reveal a monocrystalline nature using Transmission Electron Microscopy (TEM) microdiffraction analyses (Loisy et al., 1999; Borsato et al., 2000; Cailleau et al., 2009a). However, due to their tiny dimensions they are highly versatile under an electron beam and it has not been possible to accurately determine whether or not the calcite $c$ axis corresponds to the morphological nanofibre orientation (Cailleau et al., 2009a). Vergès et al. (1982) and Phillips and Self (1987) suggested a similar crystallographic orientation for both nanofibres and NFC as a result of their equivalent morphology. 
Table 1. Summary of the references mentioning nanofibres and NFC and their environment of description. For nanofibres the terminology, dimensions, and proposed origins are mentioned. For needle fibre calcite, the terminology (mainly following the terminology described in Verrecchia and Verrecchia 1994) and dimensions are mentioned.

\begin{tabular}{|c|c|c|c|c|c|c|}
\hline \multirow[t]{2}{*}{ Reference } & \multirow[t]{2}{*}{ Environment } & \multicolumn{3}{|c|}{ Nanofibres } & \multicolumn{2}{|c|}{ NFC } \\
\hline & & Terminology & $\begin{array}{l}\text { Dimensions } \mathrm{W} \text { in } \mathrm{nm} \text {, } \\
\mathrm{L} \text { in } \mu \mathrm{m}\end{array}$ & Origin & Terminology & Dimensions W/L in $\mu \mathrm{m}$ \\
\hline Klappa, 1979 & $\begin{array}{l}\text { Calcretes from the } \\
\text { western Mediterranean } \\
\text { (Spain) }\end{array}$ & Needle/hyphantic threads & W 100 and $L 1-2$ & $\begin{array}{l}\text { Described at the surface of filaments, as- } \\
\text { sumed to be resistant component of their } \\
\text { cell wall. May serve as template for miner- } \\
\text { alization }\end{array}$ & $\begin{array}{l}\text { Needle calcite/ } \\
\text { hyphantic calcite needle }\end{array}$ & Not specified \\
\hline $\begin{array}{l}\text { Vergès et al., } \\
1982\end{array}$ & $\begin{array}{l}\text { Soils (Champagne and } \\
\text { Mediterranean Midi) }\end{array}$ & Calcite en bâtonnets & W 100 & $\begin{array}{l}\text { Rapid growth from highly supersaturated } \\
\text { solutions }\end{array}$ & Calcite en aiguilles & W $1-5$ \\
\hline $\begin{array}{l}\text { Callot et al., } \\
\text { 1985b }\end{array}$ & Rendzinas on scree slopes & $\begin{array}{l}\text { Not explicitly mentioned, proba- } \\
\text { bly confused with } \\
\text { NFC }\end{array}$ & - & - & Aiguilles de calcite & $\mathrm{W} 0.1-1$ and $\mathrm{L}$ up to $0.5 \mathrm{~cm}$ \\
\hline $\begin{array}{l}\text { Phillips and } \\
\text { Self, } 1987\end{array}$ & Calcrete of South Australia & Micro-rods & W 100 or less and L 1 & $\begin{array}{l}\text { Calcified rod-shaped bacteria involved in } \\
\text { fungal sheath lysis }\end{array}$ & Needle-fibre calcite & $\begin{array}{l}\text { Smooth needles W } 0.5-2 \text { and } \\
\text { L } 2-120 \text {. Serrated edged nee- } \\
\text { dles W } 0.75-2 \text { to } 1.5-6 \text { and L } \\
7-30 \text { to } 4-90\end{array}$ \\
\hline $\begin{array}{l}\text { Jones and } \mathrm{Ng} \text {, } \\
1988\end{array}$ & $\begin{array}{l}\text { Rhizoliths in lime- } \\
\text { stones of the Pleis- } \\
\text { tocene Ironshore } \\
\text { formation }\end{array}$ & $\begin{array}{l}\text { Grain-coating calcite needle mats } \\
\text { and constituent of type II filaments }\end{array}$ & W 100 and L 6 & $\begin{array}{l}\text { Precipitation from pore-filling fluids, type } \\
\text { II filaments are calcified filaments }\end{array}$ & $\begin{array}{l}\text { Needles and calcite } \\
\text { rhomb chains }\end{array}$ & Rhomb chains W 4 and L 100 \\
\hline $\begin{array}{l}\text { Ould Mo- } \\
\text { hamed and } \\
\text { Bruand, } 1994\end{array}$ & $\begin{array}{l}\text { Cambisol developed } \\
\text { on cryoturbated Miocene la- } \\
\text { custrine } \\
\text { limestones }\end{array}$ & Micro-rods & W $100-500$ and L $1-3$ & $\begin{array}{l}\text { Calcified bacteria that grew from or- } \\
\text { ganic matter of hyphae. Mention filaments } \\
\text { whose "walls are made of micro-rods" }\end{array}$ & $\begin{array}{l}\text { Needle calcite and } \\
\text { serrated-edged needle }\end{array}$ & $\begin{array}{l}\text { Needle W } 1-3 \text { and } L 10-60 \\
\text { serrated-edged needles W } 4- \\
6 \text { and } L 10-25\end{array}$ \\
\hline $\begin{array}{l}\text { Verrecchia and } \\
\text { Verrecchia, } 1994\end{array}$ & $\begin{array}{l}\text { Carbonate soils and } \\
\text { calcretes }\end{array}$ & Micro-rods (M-type NFC) & $\mathrm{W}<500$ and $\mathrm{L}<2$ & $\begin{array}{l}\text { Physicochemical nuclei or calcified bacte- } \\
\text { ria }\end{array}$ & Needle-fibre calcite & L from 4 to 104 their $\mathrm{W}$ \\
\hline $\begin{array}{l}\text { Dubroeucq et al., } \\
1996\end{array}$ & $\begin{array}{l}\text { Volcanic ash soils associated } \\
\text { to pine trees }\end{array}$ & $\begin{array}{l}\text { Identified as actinomycetes fila- } \\
\text { ments }\end{array}$ & W 100 & $\begin{array}{l}\text { Microbial filaments organized in mats, ge- } \\
\text { netic link with NFC }\end{array}$ & Needle fibre calcite & W $0.5-1$ \\
\hline $\begin{array}{l}\text { Newman et al., } \\
1996\end{array}$ & $\begin{array}{l}\text { Pedogenic calcite from New } \\
\text { Mexico }\end{array}$ & $\begin{array}{l}\text { Gel-like material associated with } \\
\text { apparent bacterial } \\
\text { forms }\end{array}$ & Not specified & Not specified & $\begin{array}{l}\text { Calcite which consist of ap- } \\
\text { parent fungal fibres }\end{array}$ & Not specified \\
\hline Anand et al., 1997 & $\begin{array}{l}\text { Calcretes developed } \\
\text { on greenstone, Western } \\
\text { Australia }\end{array}$ & $\begin{array}{l}\text { Single micro-rod with round ter- } \\
\text { mination }\end{array}$ & $\mathrm{L}$ up to 20 & $\begin{array}{l}\text { Calcified rod-shaped bacteria } \\
\text { (Phillips and Self, 1987) }\end{array}$ & $\begin{array}{l}\text { Needles (com- } \\
\text { monly branched) } \\
\text { and serrated-edged } \\
\text { needles }\end{array}$ & $\begin{array}{l}\text { Needles: W } 0.5-2 \text { and L } 20- \\
\text { 160. Serrated-edged needles: } \\
\text { W } \\
5-25\end{array}$ \\
\hline $\begin{array}{l}\text { Gradziński et al., } \\
1997\end{array}$ & $\begin{array}{l}\text { Moonmilk from } \\
\text { a karstic cave, Poland }\end{array}$ & $\begin{array}{l}\text { Interpreted as a filamentous bacte- } \\
\text { rial mat }\end{array}$ & Not specified & $\begin{array}{l}\text { Autolytical mineralization of filamentous } \\
\text { bacterial mats, genetic link with NFC }\end{array}$ & Needle fibre calcite & Not specified \\
\hline $\begin{array}{l}\text { Cañaveras et al., } \\
1999\end{array}$ & $\begin{array}{l}\text { Karstic (partly dolomitized) } \\
\text { cave with calcite/aragonite } \\
\text { moonmilk }\end{array}$ & $\begin{array}{l}\text { Mentioned as filamentous micro- } \\
\text { bial films embedding NFC }\end{array}$ & W $100-200$ and L 5 & Identified as organic features & Needle-fibre aragonite & $\begin{array}{l}\text { Smooth single needles: W } \\
0.5-1 \text { and L } 50 \text { Polycrystals: } \\
\text { W 2-20 and L 10-100 }\end{array}$ \\
\hline $\begin{array}{l}\text { Loisy et al., } \\
1999\end{array}$ & $\begin{array}{l}\text { Indurated horizons } \\
\text { in a present-day soil rendz- } \\
\text { ina overlying } \\
\text { periglacial chalk formation }\end{array}$ & $\begin{array}{l}\text { M-type NFC or micro-rods. Two } \\
\text { types mentioned: } \\
\text { smooth and single rods and } \\
\text { smooth flexible threadlike rods }\end{array}$ & $\begin{array}{l}\text { 1st cat: W } 150 \text { and L } \\
2-3.2 \text { nd cat: W } 80 \text { and } \\
\text { L 2-6 }\end{array}$ & $\begin{array}{l}\text { Centripetal calcification around an organic } \\
\text { nucleus, likely rod-shaped bacteria }\end{array}$ & $\begin{array}{l}\text { Needle-fibre calcite } \\
\text { (MA and MB types) }\end{array}$ & $\begin{array}{l}\text { MA type: } W 0.5-2 \text { and } L< \\
100 \text {. MB type: } W 2-20 \text { and } L \\
30-1000\end{array}$ \\
\hline $\begin{array}{l}\text { Borsato et al., } \\
2000\end{array}$ & $\begin{array}{l}\text { Moonmilk in Italian } \\
\text { caves (fossil deposits after } \\
\text { radiocarbon } \\
\text { dating) }\end{array}$ & Nanofibres & W $50-150$ and $\mathrm{L}>10$ & $\begin{array}{l}\text { Physicochemical origin, crystal growth by } \\
\text { VLS mechanism. Observed as constituent } \\
\text { of filaments, identified as calcified fila- } \\
\text { ments }\end{array}$ & Microfibres & W $0.5-2$ and $L>10$ \\
\hline $\begin{array}{l}\text { Gillet et al., } \\
2000\end{array}$ & $\begin{array}{l}\text { Tataouine meteorite, south } \\
\text { Tunisia }\end{array}$ & Rod-shaped forms (RSF) & $\begin{array}{l}\text { W } 70-80 \text { and } \mathrm{L} 0.1- \\
0.6\end{array}$ & Remnants or real rod-shaped bacteria & Not observed & - \\
\hline $\begin{array}{l}\text { Cañaveras et al., } \\
2001\end{array}$ & $\begin{array}{l}\text { Karstic (partly dolomitized) } \\
\text { cave with calcite/aragonite } \\
\text { moonmilk }\end{array}$ & $\begin{array}{l}\text { Actinomycetes hyphal networks, } \\
\text { embedding NFC }\end{array}$ & $\mathrm{W}<200$ and $\mathrm{L}<2$ & Identified as organic features & Needle-fibre calcite & W $1-2$ and $L>5$ \\
\hline $\begin{array}{l}\text { Benzerara et al., } \\
2003\end{array}$ & $\begin{array}{l}\text { Tataouine meteorite, south } \\
\text { Tunisia }\end{array}$ & Rod-shaped nanobacteria like & $\begin{array}{l}\text { W average } 70-80, \\
\text { min. } 30 \text { and } L \text { average } \\
300-500(200-800)\end{array}$ & $\begin{array}{l}\text { Well crystallized calcite single crystals } \\
\text { with a thin outer amorphous layer. No ev- } \\
\text { idence of calcified nanobacteria, probably } \\
\text { involvement of an organic compound }\end{array}$ & Not observed & - \\
\hline $\begin{array}{l}\text { Cailleau et al., } \\
2005\end{array}$ & $\begin{array}{l}\text { Tropical soils containing } \\
\text { bio-induced calcite }\end{array}$ & M type microrods & W 100 and L 2-3 & $\begin{array}{l}\text { Calcified rod-shaped bacteria (after Loisy } \\
\text { et al., 1999) }\end{array}$ & $\begin{array}{l}\text { Needle fibre calcite (MA and } \\
\text { MAB types) }\end{array}$ & $\begin{array}{l}\text { MA type: W } 0.4 \text { and L } 150- \\
200\end{array}$ \\
\hline $\begin{array}{l}\text { Bajnóczi and } \\
\text { Kovács-Kis, } 2006\end{array}$ & $\begin{array}{l}\text { Paleosol in quaternary } \\
\text { travertines in Hungary }\end{array}$ & Microrods or M-type NFC & W 50-200 and L 0.5-2 & $\begin{array}{l}\text { Physicochemical nuclei or calcified bacte- } \\
\text { ria }\end{array}$ & Needle-fibre calcite & $\begin{array}{l}\text { W } 1 \text { for smooth needles and } \\
1-4 \text { for serrated-edged nee- } \\
\text { dles and L average } 40-100 \text {, } \\
\text { up to } 200\end{array}$ \\
\hline $\begin{array}{l}\text { Cañaveras et al., } \\
2006\end{array}$ & Moonmilk in caves & Filaments, bacterial hyphae & $\begin{array}{l}\text { W } 100-500 \text { and L 5- } \\
200\end{array}$ & $\begin{array}{l}\text { Fibrous structures synthesized through } \\
\text { a solution-precursor } \\
\text { (organic)-solid mechanism }\end{array}$ & $\begin{array}{l}\text { Monocrystalline rods and } \\
\text { polycrystals } \\
\text { (rhomb chains), similar } \\
\text { to needle-fibre crystals } \\
\text { described by Verrecchia and } \\
\text { Verrecchia, } 1994\end{array}$ & $\begin{array}{l}\text { Monocrystals: } \mathrm{W} 0.2-2 \text { and } \mathrm{L} \\
100-300\end{array}$ \\
\hline $\begin{array}{l}\text { Alonso-Zarza and } \\
\text { Jones, } \\
2007\end{array}$ & $\begin{array}{l}\text { Root calcrete formation on } \\
\text { quaternary karstic surfaces, } \\
\text { Bahamas }\end{array}$ & $\begin{array}{l}\text { Micro-rods but confusion with } \\
\text { NFC as also mentioned as needles }\end{array}$ & $\begin{array}{l}\text { W } 80 \text { and L } 0.3 \text {, found } \\
\text { around } \\
\text { microborings, as ag- } \\
\text { gregates or on sur- } \\
\text { face of calcified fil- } \\
\text { aments. Larger fibres } \\
\text { mentioned, W } 100 \text { and } \\
\text { L } 2 \text {, located in pores } \\
\text { and at outermost part } \\
\text { of microboring walls. }\end{array}$ & $\begin{array}{l}\text { Biogenic origin, possibly related to bac- } \\
\text { teria or fungi, but physicochemical origin } \\
\text { also possible }\end{array}$ & Needle-fibre calcite & Not specified \\
\hline $\begin{array}{l}\text { Blyth and } \\
\text { Frisia, 2008 }\end{array}$ & $\begin{array}{l}\text { Cold high-altitude } \\
\text { caves, North Italy }\end{array}$ & Nanofibres & $\begin{array}{l}\text { W } 50-150 \text { and } L 1-> \\
10\end{array}$ & $\begin{array}{l}\text { Precipitation by inorganic processes, elon- } \\
\text { gated shape as a result of polymers in so- } \\
\text { lution }\end{array}$ & Needle-fibre crystals & $\mathrm{L} / \mathrm{W}$ ratio of $>6 / 1$ \\
\hline $\begin{array}{l}\text { Richter et al., } \\
2008\end{array}$ & $\begin{array}{l}\text { Moonmilk in caves } \\
\text { in Devonian massive lime- } \\
\text { stones }\end{array}$ & $\begin{array}{l}\text { Nanofibres as constituents of (1) } \\
\text { "polycrystalline } \\
\text { threads characterized by a cen- } \\
\text { tral channel" and (2) "irregularly } \\
\text { shaped polycrystalline mats which } \\
\text { bind or cover NFC and threads" }\end{array}$ & W $50-100$ and $\mathrm{L}<10$ & Not specified & Needle-shaped crystals & W $0.5-2(5)$ and $\mathrm{L}$ up to 200 \\
\hline
\end{tabular}


Table 1. Continued.

\begin{tabular}{|c|c|c|c|c|c|c|}
\hline \multirow[t]{2}{*}{ Reference } & \multirow[t]{2}{*}{ Environment } & \multicolumn{3}{|c|}{ Nanofibres } & \multicolumn{2}{|c|}{ NFC } \\
\hline & & Terminology & $\begin{array}{l}\text { Dimensions } \mathrm{W} \text { in } \mathrm{nm}, \\
\mathrm{L} \text { in } \mu \mathrm{m}\end{array}$ & Origin & Terminology & Dimensions W/L in $\mu \mathrm{m}$ \\
\hline $\begin{array}{l}\text { Cailleau et al., } \\
\text { 2009a }\end{array}$ & $\begin{array}{l}\text { Pedogenic and karstic envi- } \\
\text { ronments }\end{array}$ & Nanofibres & $\begin{array}{l}\text { W } 19-30 \text { and } \mathrm{L} \text { up to } \\
1.6\end{array}$ & $\begin{array}{l}\text { Pseudomorphosis of organic polymers } \\
\text { (e.g. cellulose) by supersaturated pore- } \\
\text { filling fluids }\end{array}$ & Needle fibre calcite & W approx. 2 \\
\hline $\begin{array}{l}\text { Cailleau et al., } \\
2009 \mathrm{~b}\end{array}$ & $\begin{array}{l}\text { Calcareous soils from } 11 \\
\text { sites in various climates }\end{array}$ & $\begin{array}{l}\text { Mentioned in Cailleau et al., } \\
\text { 2009a }\end{array}$ & - & - & Needle fibre calcite & L from 4 to 104 their $\mathrm{W}$ \\
\hline $\begin{array}{l}\text { Curry et al., } \\
2009\end{array}$ & Karstic caves, Alaska & $\begin{array}{l}\text { Nano-fibres, mostly associated to } \\
\text { NFC monocrystals }\end{array}$ & $\mathrm{W}<1$ & Biologically influenced organomineral & Needle-fibre calcite & $\begin{array}{l}\text { Monocrystals: W } 1-3 \text { and L } \\
30-267 \text { and polycrystals W } \\
6-24 \text { and L } 45-126\end{array}$ \\
\hline $\begin{array}{l}\text { Zhou and } \\
\text { Chafetz, } 2009\end{array}$ & $\begin{array}{l}\text { Biogenic caliche in Texas } \\
\text { along a climatic gradient } \\
\text { (moist subhumid to aridic) }\end{array}$ & Micro-rods & Not specified & Related to microbial activity & Needle fibre calcite & $\begin{array}{l}\text { W } 0.5-2 \text { and } L \text { average } 10- \\
50 \text {, up to } 100\end{array}$ \\
\hline $\begin{array}{l}\text { Gradziński et al., } \\
2012\end{array}$ & $\begin{array}{l}\text { Moonmilk from } \\
\text { a karstic cave, } \\
\text { Slovakia }\end{array}$ & Filamentous calcite crystals & $\begin{array}{l}\text { W } 200-500 \text { and } \mathrm{L}< \\
10\end{array}$ & $\begin{array}{l}\text { Three-dimensional calcite replicas of bac- } \\
\text { terial cells (due to bacterial activity }= \\
\text { biologically-influenced mineralization) }\end{array}$ & $\begin{array}{l}\text { Needle calcite crystals } \\
\text { (Needle-fibre calcite) }\end{array}$ & Not specified \\
\hline
\end{tabular}

TEM measurements performed by Loisy et al. (1999) show a similar result, with the nanofibre length being parallel to the (104) direction. However, Borsato et al. (2000) show that the nanofibre morphologic orientation is parallel to the calcite $c$ axis. They have been able to measure nanofibres' crystallographic orientation, probably because of the presence of strongly mineralized nanofibres. Indeed their TEM images suggest the presence of indentation on their surface (Borsato et al., 2000; their Figure 7d), which had probably allowed them to perform a microdiffraction analysis all along the three zone axes of the crystal to be able to deduce an accurate diffraction pattern. Richter et al. (2008) were not able to measure crystallographic orientations of nanofibres with Electron Backscatter Diffraction (EBSD) due to their small sizes. As a result, no clear answer regarding the crystallographic orientations of nanofibres is available at present, due to the technical limitations put forth by Cailleau et al. (2009a) and Richter et al. (2008), as well as the contradictory results obtained by Loisy et al. (1999) and Borsato et al. (2000).

Nanofibres correspond to the M-type micro-rods described by Verrecchia and Verrecchia (1994) as proposed by Borsato et al. (2000) and later summarized by Cailleau et al. (2009a). They have been known in the scientific community for a long time, but, in many studies, have been either set aside in favour of NFC or probably wrongly interpreted as microbial filaments (Dubroeucq et al., 1996; Gradziński et al., 1997; Cañaveras et al., 1999). Due to this, many different names have been given to these features (Table 1), and no consensus currently exists.

Nanofibres do not show extensive types of morphologies, their surfaces appear smooth and their cross section is round to pseudohexagonal (Loisy et al., 1999; Borsato et al., 2000). They are usually observed arranged into meshes that can either be randomly organized (nanofibres randomly distributed; Fig. 1a) or show an organized pattern (nanofibres showing preferential orientations or organization; Fig. 1b, c; see also Bindschedler et al., 2010). Ultimately they can also be found sparsely distributed associated with NFC (Fig. 1d).

\subsection{Needle fibre calcite}

NFC is also a needle-like, or acicular habit of usually lowMg calcite (Phillips and Self, 1987; Verrecchia and Verrecchia, 1994; Bajnóczi and Kovács-Kis, 2006; Cañaveras et al., 2006; Richter et al., 2008). It has larger dimensions than nanofibres with an average width of $1-2 \mu \mathrm{m}$ and a length from 4 to $10^{2}$ times their width (Table 1). It is a monocrystalline habit of calcite (Vergès et al., 1982; Phillips and Self, 1987; Borsato et al., 2000; Richter et al., 2008; Cailleau et al., 2009b) and several authors have demonstrated that the needle growth axis exhibits a deviation from the calcite $c$ axis using different methods. (Optical method: Iwanoff, 1906; Mügge, 1914. Electron microdiffraction pattern obtained with TEM: Vergès et al., 1982; Phillips and Self, 1987. EBSD: Richter et al., 2008.) This calcitic habit has been described by several authors under different names (Table 1) until Stoops (1976) introduced the term "needle fibre calcite" that is nowadays the accepted terminology.

Two main morphologies of NFC are observed: monocrystalline rods and polycrystalline chains after Verrecchia and Verrecchia (1994) terminology. Monocrystalline rods may exhibit several morphologies, with either a smooth or a serrated edge. Intermediate forms are also observed. At the scale of a single needle, a myriad of different shapes (either longitudinally or transversally) may be recognized, as reviewed in Cailleau et al. (2009b) and synthesized in their Fig. 3. This is the result of slight variations at the surface of needles and, as a result, an exhaustive classification of all morphologies is not possible (Cailleau et al., 2009b). At a larger scale, needles may be organized into mesostructures, arranged either as random meshes or as bundles that may be ramified or not (Bindschedler et al., 2012). Importantly, nanofibres are almost always associated with NFC as a distinct feature (Figs. 1 and 2).

In addition, calcified filaments, as well as fungal hyphae coated with calcium oxalate, are regularly observed in association with NFC and nanofibre accumulations (Klappa, 1979; Callot et al., 1985b; Phillips et al., 1987; Verrecchia and Dumont, 1996), which represent as well indicators of great value 

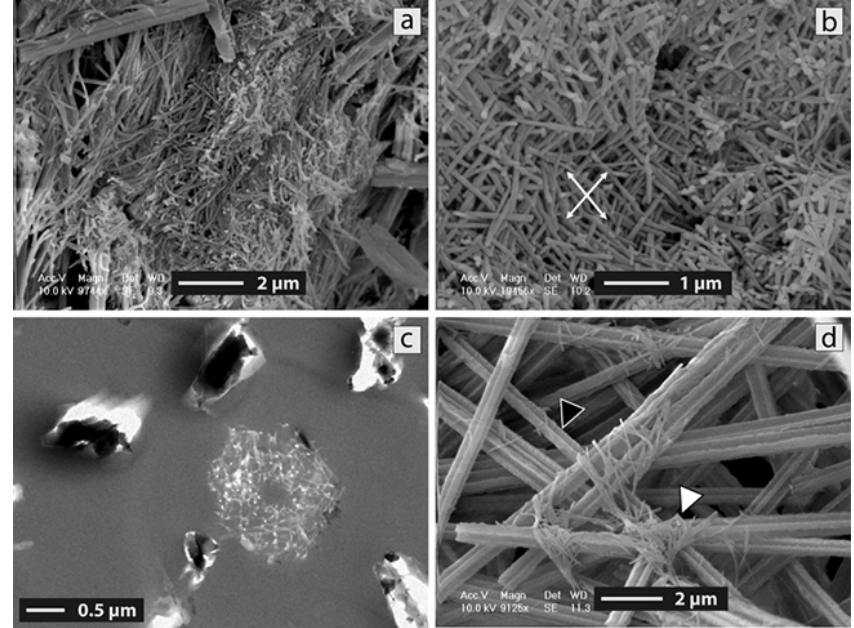

Figure 1. Electron microscope images of different nanofibres organization. (a, b, d) SEM images, (c) TEM image. (a, b) Secondary $\mathrm{CaCO}_{3}$ sample from a mineral soil horizon. (c, d) Sample from secondary $\mathrm{CaCO}_{3}$ coatings on scree deposits containing decaying fungal rhizomorphs. (a) Randomly organized mesh of nanofibres. (b) Organized mesh of nanofibres; note the preferential orientation of nanofibres (white arrows). (c) Transversal view of an organized mesh of nanofibres; note that nanofibres were removed while sectioning the sample and only their imprint in the resin remains; (d) Sparsely distributed nanofibres (white arrow), lying on needle surfaces (black arrow)

regarding the environmental parameters favouring NFC and nanofibre formation.

\subsection{Differences between nanofibres and NFC}

NFC and nanofibres are a truly distinct habit of low-Mg calcite, as several characteristic differences may be highlighted. Nanofibres sometimes show patterns that have been interpreted as the result of a contact deformation (Fig. 2a; Cailleau et al., 2009a). These kinds of features have never been observed on NFC crystals, that are much more brittle features. Nanofibres are smooth single rods displaying a constant round section and, as emphasized by Phillips and Self (1987), no evidence of alteration of this shape has been observed. In contrast, NFC exhibits a wide range of morphologies (cross section and/or surface) varying from double rods to complex serrated forms as emphasized by Phillips and Self (1987), Verrecchia and Verrecchia (1994), and Cailleau et al. (2009b). Moreover, NFC often displays slight defects at its surface, whereas nanofibres have always a smooth appearance (Fig. 2a).

Several authors point to the fact that they most likely have no genetic link, based on the points above and on their differences in dimensions (Phillips and Self, 1987; Ould Mohamed and Bruand, 1994; Loisy et al., 1999; Bajnóczi and Kovács-Kis, 2006; Cailleau et al., 2009a). However, the fact that they are frequently observed together, often displaying
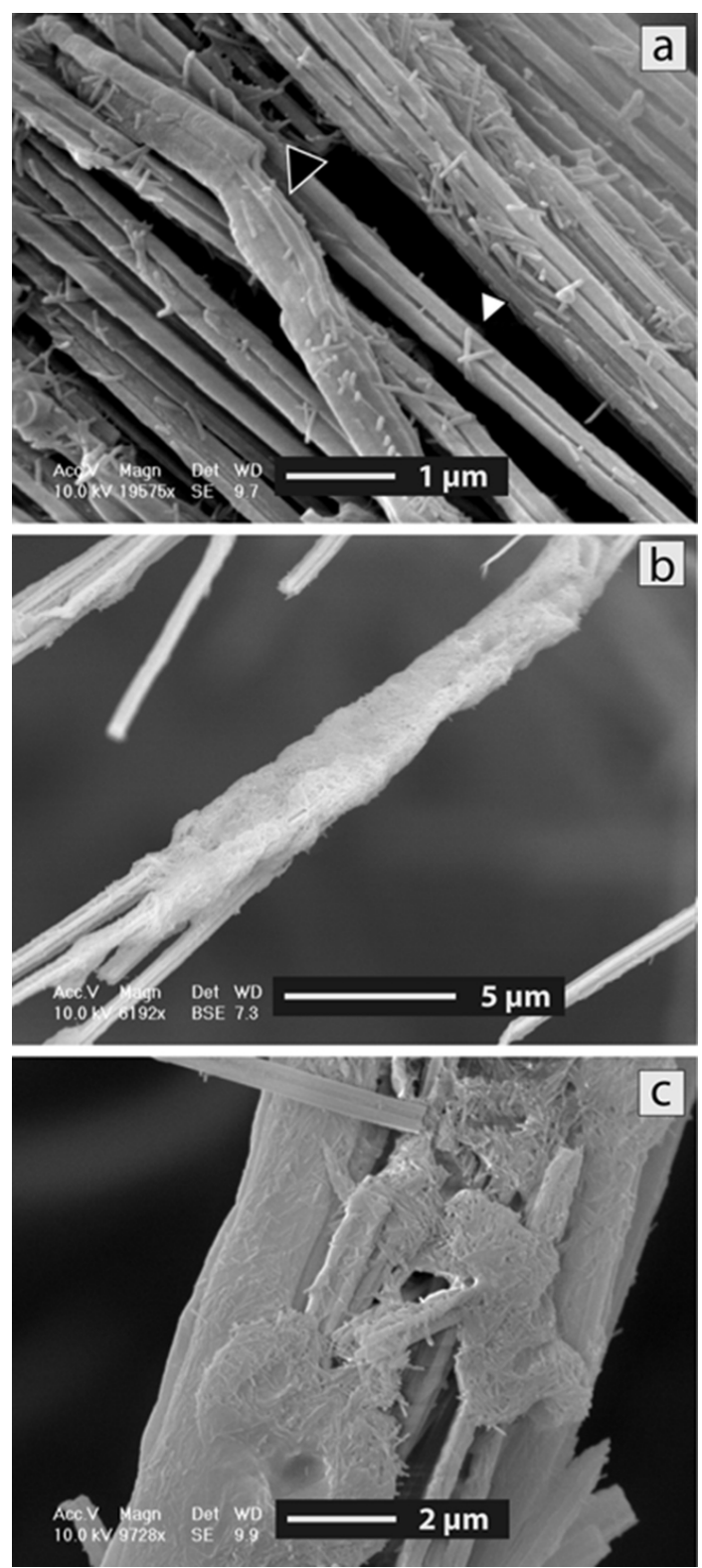

Figure 2. SEM images showing the main differences and relationships between NFC and nanofibres. Samples of both organic matter and secondary $\mathrm{CaCO}_{3}$ located at the interface between the organic and mineral soil horizons. (a) NFC showing an irregular shape and surface defects (black arrow), whereas nanofibres have a smooth appearance, as well as contact deformation features (white arrow); note that both features have truly different dimensions. (b) LTSEM image of a bundle of NFC embedded in a nanofibre mesh. (c) NFC bundle showing nanofibre meshes lying on it.

an intimate relationship (Fig. 2b, c), suggests that a related but non-genetic origin may be considered. In this paper, the term genetic is used to relate to the origin of something and not to its heredity. As a result, a clear distinction between both habits is crucial and will lead to a better understanding of the condition leading to their formation. 


\subsection{Hypotheses for the origin of nanofibres}

As mentioned earlier, the origin of nanofibres is still a subject of controversy and these nanofeatures remain largely enigmatic at present (Table 1). This is mainly due to the methodological limitations inherent in the fine study of sub-micrometric size objects. Indeed, until a few years ago, no method was available with a spot size small enough to focus on one nanofibre in detail without damaging the sample (Richter et al., 2008; Cailleau et al., 2009a). In addition, the fact that nanofibres are very often observed in close association with NFC has probably put nanofibres in the background of NFC features. Several authors have either inaccurately assimilated them into bacterial mats (Cañaveras et al., 1999) and/or thought they were genetically related to NFC (Dubroeucq et al., 1996; Gradziński et al., 1997). However, some authors have attempted to critically discuss their origin either briefly or as a whole study (Klappa, 1979; Phillips and Self, 1987; Loisy et al., 1999; Borsato et al., 2000; Benzerara et al., 2003; Cailleau et al., 2009a). Moreover, considering the origin of a feature with such dimensions, numerous hypotheses linked to nanobacteria-like objects can be discussed. Current hypotheses proposed for the origin of calcitic nanofibres are (i) purely physicochemical processes, (ii) mineralization of rod-shaped bacteria, and (iii) the involvement of an organic template as a nucleation enhancer and/or crystal growth modifier.

\subsubsection{Physicochemical processes}

Several authors have proposed a physicochemical origin for nanofibres (Vergès et al., 1982; Jones and Ng, 1988; Jones and Khale, 1993; Borsato et al., 2000; Jeong and Chun, 2006). This hypothesis is mainly based on the fact that the elongated shape of these crystals is the result of a precipitation and crystalline growth due to rapid evaporation from a highly supersaturated solution in an aridic environment (Buckley, 1951; Vergès et al., 1982; Jones and Ng, 1988; Jones and Khale, 1993; Jeong and Chun, 2006). Borsato et al. (2000), in their study on cave moonmilk, propose that the defect-free pattern of nanofibres is the result of a vapourliquid-solid (VLS) mechanism. This process typically allows the growth of a crystal into the shape of a nanofibre from a vapour phase. A liquid phase is created at the tip of the fibre, incorporating constituents of the vapour phase. This leads to a rise in the supersaturation level and thus reduces the surface energy for subsequent crystal growth (Olszta et al., 2004; Zhu et al., 2009). They support their hypothesis by the facts that cave atmosphere is saturated with water vapour and that hydro-aerosols as well as dust containing $\mathrm{Ca}^{2+}$ and $\mathrm{CO}_{3}^{2-}$ may be present in the cave environment. Given these observations, unidirectional growth of a calcite crystal may occur through a VLS growth mechanism. In another study performed by Kellermeier et al. (2012), it was shown that total silica content in the crystallization environment could lead to $\mathrm{CaCO}_{3}$ with needle-like shapes, mainly through the stabilization of initial amorphous $\mathrm{CaCO}_{3}$ (ACC) by silica coatings. Calcite crystal growth is subsequently affected by combined adsorption and precipitation phenomena.

\subsubsection{Calcification of rod-shaped bacteria}

Several authors have proposed the mineralization of rodshaped bacteria to be at the origin of nanofibres (Phillips and Self, 1987; Ould Mohamed and Bruand, 1994; Verrecchia and Verrecchia, 1994; Dubroeucq et al., 1996; Gradziński et al., 1997; Loisy et al., 1999). This hypothesis is mostly based on morphological similarities. Indeed, nanofibres form densely intertwined meshes that may look like bacterial mats. As a consequence, some authors have directly identified these nanofibre mats as microbial mats (supposedly Actinomycetes) using electron microscopy (Dubroeucq et al., 1996; Gradziński et al., 1997; Cañaveras et al., 1999; Loisy et al., 1999). Gradziński et al. (1997), as well as Loisy et al. (1999), proposed a subsequent calcification of these microbial mats. Phillips and Self (1987), as well as Ould Mohamed and Bruand (1994), interpret nanofibres as being calcified rodshaped bacteria that were actively associated with the decay of fungal hyphae and/or rhizomorphs. They based their hypothesis on the work of Boquet et al. (1973) who demonstrated that soil bacteria where able to induce calcite crystal formation. Importantly, regarding average sizes of nanofibres, the hypothesis of the mineralization of rod-shaped bacteria suggests that these bacteria are rather nanobacteria. Yet, a controversy exists regarding the putative existence of nanobacteria (Folk, 1993; Kirkland et al., 1999; Folk and Lynch, 2001; Schieber and Arnott, 2003; Martel and Young, 2008; Young et al., 2009; Pacton and Gorin, 2011).

\subsubsection{Involvement of an organic template}

Alternative origins for nanofibres propose the involvement of organic templates. These latter may act as enhancers of calcite nucleation and/or as crystal growth and shape modifiers (Benzerara et al., 2003; Benzerara et al., 2005; Olszta et al., 2004; Cailleau et al., 2009a; Zhu et al., 2009). This hypothesis lies between physicochemical and biogenic processes, as it involves the presence of organic matter, but the processes of precipitation and crystal growth do not necessarily happen as the direct result of a biological activity. This type of process may be defined as organomineralization as discussed in Perry et al. (2007) or biologically influenced biomineralization as defined by Dupraz et al. (2009). Several studies related to biomimetics have attempted to reproduce the nanofibre shape using template-assisted synthesis and successfully achieved it (Olszta et al., 2004; Homeijer et al., 2008; Zhu et al., 2009). However, it must be pointed out that experimental protocols usually poorly reproduce conditions from the natural environment. Yet, Olszta et al. (2004) have artificially produced monocrystalline calcitic nanofibres with striking 


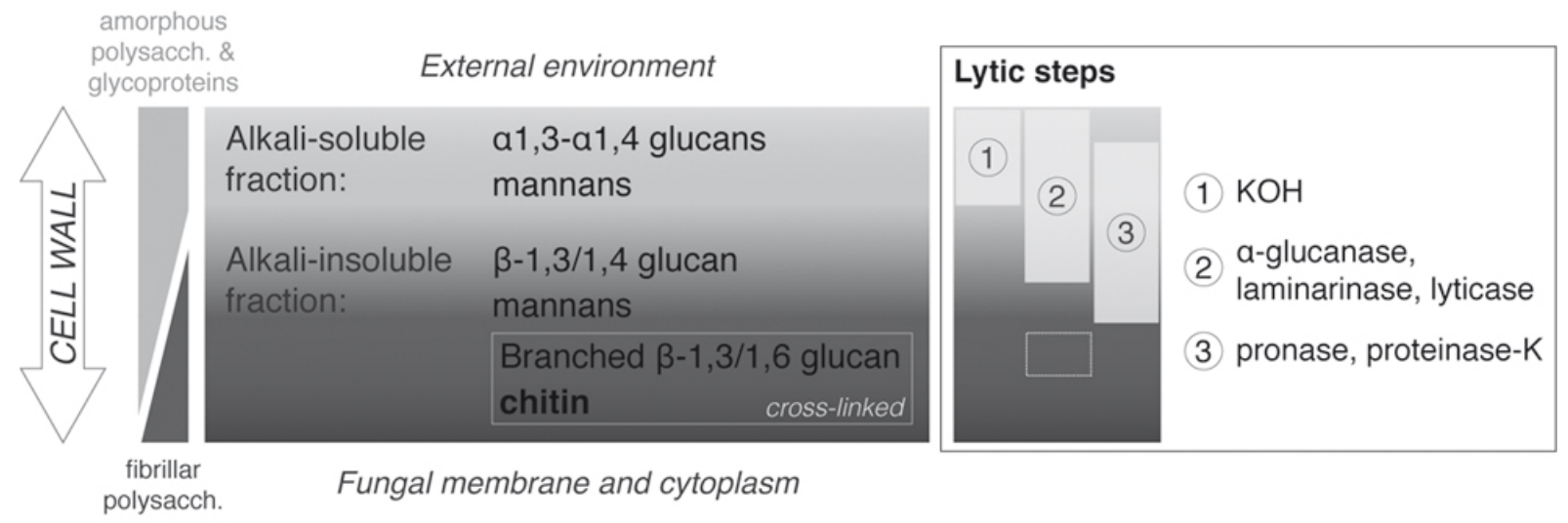

Figure 3. Basic biochemical composition of fungal cell wall (right hand side) associated with the experimental design applied (left hand side). The outermost layer, designated the alkali-soluble fraction, is made of amorphous $\alpha$-glucans and mannans and constitutes an amorphous matrix. It is digested with $5 \% \mathrm{KOH}$ (lytic step 1), followed by $\alpha$-glucanase (lytic step 2). The innermost layer, called the alkali-insoluble layer, is made of different type of $\beta$-glucans and of chitin and constitutes a structural scaffold. Cross-linked chitin is located at the innermost part of the cell wall. $\beta-1,3 / 1,4$ glucan located towards the outer part of the alkali-insoluble fraction are digested by laminarinase and lyticase (lytic step 2). Note that it is possible that some branched $\beta-1,3 /-1,6$ glucan from the cross-linked network of chitin and $\beta$-glucan may be digested as well (dashed square). The glycoproteins (mainly mannoproteins) that are distributed discretely in the cell wall structure are digested by pronase and proteinase-K (lytic step 3). After these treatments, only chitin and branched $\beta-1,3 /-1,6$ glucan of the cross-linked structural scaffold remain.

similarities to both NFC and nanofibres using a solutionprecursor-solid mechanism. Briefly, pre-existing calcite substrate crystals were coated with a polymer-based precursor composed of acidic macromolecules, immersed in a Ca-rich solution and exposed to $\mathrm{CO}_{2}$ vapours at room temperature. This process explains nicely the elongated nanofibres' shape. However, these synthetic fibres lack the usual smooth appearance of natural nanofibres. Closer to environmental conditions, Cailleau et al. (2009a) have proposed the involvement of naturally occurring nanofibrous polymers, such as cellulose. The nucleation of calcite on organic fibrous polymers has been demonstrated in laboratory experiments by several authors (Manoli et al., 1997; Dalas et al., 2000; Cailleau et al., 2009a; Ehrlich, 2010). Nanofibrous organic polymers are widespread features of biological systems as components of the cell walls of plants and fungi (Paul, 2007). Moreover, they are arranged in higher-order structures, i.e. the cells and the organism made of these cells. As mentioned earlier, an indirect biogenic origin involving organic nanofibres originating from cell wall material has already been suggested in the past (Klappa, 1979; Cailleau et al., 2009a; Bindschedler et al., 2010). Indeed, the cell walls of fungi, as well as of plants, are a potential source of organic nanofibres, as fibrous polymers are common components of both types of organisms (Carlile et al., 2001; Paul, 2007).

Due to the fact that nanofibres are observed in the presence of NFC, which is thought to be the result of fungal biomineralization (Callot et al., 1985a; Phillips and Self, 1987; Ould Mohamed and Bruand, 1994; Verrecchia and Verrecchia, 1994; Cailleau et al., 2009b; Bindschedler et al., 2010, 2012; Millière et al., 2011a), this paper will focus on the de- scription on the fungal cell wall rather that the plant cell wall. However, it must be pointed out that as both types of organisms have a fibrous component within their cell wall, the conclusion drawn for organic nanofibres of fungal origin could also be valid for organic nanofibres of plant origin.

\subsection{The fungal cell wall and its nanofibrous component}

To understand the link between the genesis of organic nanofibres and the fungal cell wall, it is necessary to take a closer look at the fungal cell wall structure. The precise composition of the fungal cell wall is dependant on the fungal taxa, but it is commonly composed of two main sheets: an inner structural layer made of fibrous polysaccharides and an outer matrix made of amorphous polysaccharides, largely enveloping the structural layer (Bartnicki-García, 1968; Burnett, 1979; Farkaš, 1979; Ruiz-Herrera, 1992; Bowman and Free, 2006; Latgé, 2007; Webster and Weber, 2007; Fig. 3). The transition from the structural to the amorphous part is gradual. The amorphous matrix, which is located at the outermost part, is constituted mainly of amorphous $\alpha-1,3$ and $\alpha-1,4$ glucans and glycoproteins (mostly mannans) and is referred to as the alkali-soluble fraction of the cell wall. The structural layer, located at the innermost part, is made mainly of fibrous polymers, chitin linked to branched $\beta-1,3 /$ 1,6 glucan and $\beta-1,3 /-1,4$ glucan, and is referred to as the alkali-insoluble fraction of the cell wall. It is, in large part, enveloped by the amorphous matrix (Hunsley and Burnett, 1970; Ruiz-Herrera, 1992; Farkaš, 2003; Latgé, 2007; Webster and Weber, 2007). Furthermore, cross-linking between chitin, $\beta-1,3 /-1,6$ glucan and glycoproteins in the fibrillar 
layer results in an enhanced rigidity of the cell wall and is the reason for the insolubility of this part in hot alkali solution (Fontaine et al., 1997, 2000; Bowman and Free, 2006; Latgé, 2007). Chitin is a polymer of $\mathrm{N}$-acetylglucosamine and is present in the form of long microfibrils (up to $1 \mu \mathrm{m}$ ), with diameters between 10 to $25 \mathrm{~nm}$ (Carlile et al., 2001). It is located in the innermost part of the wall and arranged as an intertwined mesh embedded in an amorphous matrix of mannoproteins (Aronson and Preston, 1960; Carlile et al., 2001; Bowman and Free, 2006). $\beta$-glucans are polymers of D-glucose. In the fibrous region of the fungal wall, they are present as branched $\beta-1,3 /-1,6$ glucan. They are usually found in greater amounts than chitin (Carlile et al., 2001; Farkaš, 2003; Bowman and Free, 2006).

\section{Material and methods}

\subsection{Cultures of fungal strains}

Three strains were used for enzymatic assays: one saprotroph ascomycete (Petriella sp.) and two basidiomycetes - one root parasite (Armillaria mellea) and one ectomycorrhiza (Boletus edulis). Petriella sp. and Armillaria mellea are from the culture collection of the Laboratory of Microbiology at the University of Neuchâtel and the Boletus edulis strain was obtained from the Swiss Federal Research Institute WSL (CH8903 Birmensdorf). These three strains were chosen based on the two following criteria: (i) having representatives of the two most dominant taxon (basidiomycetes and ascomycetes), (ii) as well as having the three main ecological types that can be encountered in mineral-dominated soil layers from temperate forest ecosystems (saprotrophs, parasites and ectomycorrhizal). Petriella sp. and A. mellea were cultivated at room temperature away from any light source on a $1.2 \%$ malt-agar medium (malt extract $12 \mathrm{~g} \mathrm{~L}^{-1}$; agar $15 \mathrm{~g} \mathrm{~L}^{-1}$ ). B. edulis was cultivated at room temperature away from any light source on MMN medium (after Marx and Bryan, 1971): D-glucose $10 \mathrm{~g} \mathrm{~L}^{-1}$; malt extract $3 \mathrm{~g} \mathrm{~L}^{-1}$; $\left(\mathrm{NH}_{4}\right)_{2} \mathrm{HPO}_{4} 250 \mathrm{mg} \mathrm{L}^{-1}$; $\mathrm{KH}_{2} \mathrm{PO}_{4} 500 \mathrm{mg} \mathrm{L}^{-1} ; \mathrm{MgSO}_{4} .7 \mathrm{H}_{2} \mathrm{O} 150 \mathrm{mg} \mathrm{L}^{-1} ; \mathrm{FeCl}_{3}$ $12 \mathrm{mg} \mathrm{L}^{-1} ; \mathrm{CaCl}_{2} 50 \mathrm{mg} \mathrm{L}^{-1}$; $\mathrm{NaCl} 25 \mathrm{mg} \mathrm{L}^{-1}$; thiamine $0.1 \mathrm{mg} \mathrm{L}^{-1}$; agar $15 \mathrm{~g} \mathrm{~L}^{-1}$ ). All strains were cultivated in Petri dishes of $55 \mathrm{~mm}$ diameter with polycarbonate filters of $0.2 \mu \mathrm{m}$ pores set upon the solid media in order to be able to harvest solely the mycelium.

\subsection{Enzymatic incubations}

The enzymatic approach was adapted from Hunsley and Burnett (1970; Fig. 3). The rationale for choosing selected enzymes rather than filtrates of autolysing fungal cultures is principally that we wanted to avoid chitinases in order to preserve the chitin fibres. A 2-week-old mycelium was used for Petriella sp. and A. mellea, whereas a 2-month-old mycelium was used for B. edulis, as it has a slower growth rate. The whole mycelium (from the centre to the margin, with the ex- ception of the inoculum) was used for the incubations and was treated aseptically throughout the experiment. Buffer solutions and water were autoclaved, whereas enzymatic solutions were sterilized by filtration through $0.2 \mu \mathrm{m}$ nitrocellulose filters. Enzymes were mixed according to their lytic activities, either glycolytic or proteolytic. The glycolytic mix contained an alpha-glucanase $\left(10 \mathrm{U} \mathrm{mL}^{-1} ; \mathrm{EC} \mathrm{3.2.1.20),}\right.$ a lyticase $\left(150 \mathrm{U} \mathrm{mL}^{-1}\right.$; EC 3.2.1.58) and a laminarinase (7 $\mathrm{U} \mathrm{mL}^{-1}$; EC 3.2.1.6). The proteolytic mix contained a protease $\left(50 \mathrm{U} \mathrm{mL}^{-1}\right.$; commercial mixture of at least three proteolytic activities) and a proteinase $\mathrm{K}\left(50 \mathrm{U} \mathrm{mL}^{-1}\right.$; EC 3.4.21.64). All enzymes were supplied by Sigma-Aldrich ${ }^{\mathrm{TM}}$ and incubation conditions were set in agreement with the enzymatic optimal efficiency according to Sigma-Aldrich ${ }^{\mathrm{TM}}$ information.

Mycelia were treated without a prior step of washing. They were separated from the polycarbonate filter and transferred to a $2 \mathrm{~mL}$ Eppendorf filled with ultrapure water, and ultrasonicated for $15 \mathrm{~min}$. Then, they were washed once in $5 \%$ $\mathrm{KOH}$, re-suspended in $1.5 \mathrm{~mL}$ fresh $5 \% \mathrm{KOH}$, and incubated at $30^{\circ} \mathrm{C}$ for 5 days. After $\mathrm{KOH}$ treatment, mycelia were washed in deionized water once, and then incubated at $37^{\circ} \mathrm{C}$ for 3 days in $1.5 \mathrm{~mL}$ glycolytic enzymatic mix in a pH 7 Z-buffer (modified after Braissant et al., 2009): $\mathrm{Na}_{2} \mathrm{HPO}_{4} 60 \mathrm{mM} ; \mathrm{NaH}_{2} \mathrm{PO}_{4} \times 2 \mathrm{H}_{2} \mathrm{O} 40 \mathrm{mM} ; \mathrm{KCl} 10 \mathrm{mM}$; $\mathrm{MgSO}_{4} \times 7 \mathrm{H}_{2} \mathrm{O} 1 \mathrm{mM}$. After this step, mycelia were washed again in deionized water once and incubated in $1.5 \mathrm{~mL}$ proteolytic enzymatic mix in a $\mathrm{pH} 8.8$ Tris-HCl buffer (Tris buffer $10 \mathrm{mM}$; $\mathrm{KCl} 10 \mathrm{mM} ; \mathrm{MgSO}_{4} \times 7 \mathrm{H}_{2} \mathrm{O} 1 \mathrm{mM}$ ) at $37^{\circ} \mathrm{C}$ for 3 days (Fig. 3). After each step mycelia were washed and then stored at $4{ }^{\circ} \mathrm{C}$ until fixation for scanning electron microscopy (SEM).

\subsection{SEM observations of laboratory samples}

All laboratory samples underwent primary fixation in $2.5 \%$ glutaraldehyde in phosphate buffer solution (PBS) and secondary fixation in $1 \%$ osmium tetroxide in PBS. Samples were then dehydrated in ethanol series of increasing concentrations with a tetramethylsilane (TMS) step for final airdrying (Dey et al., 1989). Samples were finally placed on a SEM stub and gold- and carbon-coated with thicknesses of 18 and $5 \mathrm{~nm}$, respectively. SEM was performed using a Tescan Mira LMU operated at a distance of $10 \mathrm{~mm}$ and a voltage of 10 to $15 \mathrm{keV}$ acceleration. Elemental microanalyses were performed with an EDAX energy-dispersive spectrometer (EDS) coupled to the SEM.

\subsection{Sampling of natural deposits}

Secondary $\mathrm{CaCO}_{3}$ accumulations were sampled in calcic horizons from calcic Cambisol humic calcaric (IUSS Working group WRB, 2006) developed on scree slope deposits under a beech and silver fir forest. The sampling site is a quarry 
near Villiers (Swiss Jura Mountains, $47^{\circ} 04^{\prime} \mathrm{N}, 6^{\circ} 59^{\prime} \mathrm{E}$ ). Samples were taken both at the quarry front and at the interface between B and C calcic horizons. Samples of pedogenic carbonates exhibit two different macromorphologies: (i) cotton ball-like NFC that accumulates in soil pores resulting from cryoclast packing and root voids and (ii) white coatings on centimetric to decimetric cryoclasts. Both morphologies are found in association with particulate and amorphous soil organic matter. All samples were collected using tweezers and stored in sterilized $50 \mathrm{~mL}$ tubes at $4{ }^{\circ} \mathrm{C}$.

\subsection{SEM observations of natural samples}

Samples from natural deposits were observed using two different modes of SEM: (i) high-vacuum SEM (HV-SEM) and (ii) low-temperature SEM (LTSEM). For HV-SEM purposes, natural samples were fixed with osmium tetroxide vapours after a modified protocol from Pearson et al. (2004) described in Bindschedler et al. (2010), freeze-dried, placed on a SEM stub, and gold-coated (15 nm thick). HV-SEM observations were performed using a Phillips ESEM-FEG XL30 field emission gun SEM (FEG-SEM) as well as a Tescan Mira LMU, both operated at a distance of $10 \mathrm{~mm}$ and an acceleration voltage of 10 to $15 \mathrm{keV}$. LTSEM was performed using a Gatan cryotransfer system coupled to a Phillips ESEM-FEG XL30. Natural samples were frozen in liquid nitrogen, transferred into a cryo-preparation chamber in order to remove water by sublimation and then coated with platinum $(10 \mathrm{~nm}$ thick). Samples were transferred into the observation chamber of the microscope and all observations were performed at low temperature $\left(-180^{\circ} \mathrm{C}\right)$ and high vacuum.

\subsection{Nanofibre measurements}

Diameters (observed widths) of both natural and laboratoryobtained nanofibres were measured directly from SEM images using the measurement tool of Adobe ${ }^{\mathrm{TM}}$ Photoshop $^{\mathrm{TM}}$. Data from natural nanofibres observed in randomly organized meshes were obtained from Bindschedler et al. (2010). Data from natural nanofibres observed in organized meshes as well as nanofibres produced in the laboratory were obtained from 470 and 410 measurements respectively (with 10 measures of individual nanofibres per SEM image). A oneway analysis of variance (ANOVA) was performed to see if the three different categories of nanofibres (from organized meshes, randomly organized meshes and obtained in laboratory) were significantly different regarding their diameters. A post hoc Tukey honest significant difference (HSD) test was performed to obtain the pairwise comparison. Statistical treatment was performed using the R software (R Development Core Team, 2010).

\subsection{Osmium signature of commercial chitin and $\beta$-1,3-glucan extracts}

Commercial extracts of chitin and $\beta$-1,3-glucan (both supplied by $\operatorname{Sigma}^{\mathrm{TM}}$ ) were used to test osmium tetroxide affinity for fibrillar fungal cell wall polymers (chitin and $\beta-1,3-$ glucan). They were treated in the same way as the natural samples following the procedure described above. The presence of osmium was detected using EDS.

\section{Results}

\subsection{Enzymatic digestion of the cell wall of selected fungal strains}

Each step of the treatment led to noticeable differences in hyphal surficial texture, i.e. cell wall surfaces. The cell walls of the three species used in this study, Armillaria mellea, Petriella sp., and Boletus edulis, have shown similar responses to the treatment (Fig. 4). Therefore, the results will be discussed together regardless of the species.

Untreated hyphae exhibit a granular surface and are often embedded in a fibrillar matrix of exopolysaccharidic substances (Fig. 5a). After ultrasonication of hyphae in ultrapure water for $15 \mathrm{~min}$, their surface displays a dramatic change with the appearance of a surficial fibro-reticular layer (Fig. 5b). This layer disappears totally after $\mathrm{KOH}$ treatment, revealing a smooth surface at this step (Fig. 5c). In few areas however, a close-up of the surface already shows some nanofibres, totally embedded in an amorphous matrix (Fig. 5d). Then, after the treatment with the glycolytic enzyme mix, the hypha surface shows some areas displaying meshes of organic nanofibres with a granular appearance, which are still trapped in an amorphous matrix (Fig. 5e). Finally, after incubation in the proteolytic enzyme mix, all three species show a fibrous network composed of organic nanofibres (Figs. 4 and 5f).

\subsection{Comparison with natural counterparts}

These organic nanofibres still have a granular appearance (Fig. 5f), and some of them seem to be sometimes embedded in a thin film made of an amorphous matrix. Nevertheless, their shape, as well as their organization, can be compared with their natural counterparts (Fig. 6), based on the fact that in natural samples, organized networks of nanofibres have been recognized as being organic in nature with an osmium labelling method (Bindschedler et al., 2010).

Meshes of natural nanofibres organized in tube-like structures (Fig. 6a) are analogous to a transversal view of a hypha after the enzymatic treatment (Fig. 6b). Nest-like structures (as defined in Bindschedler et al., 2012; Fig. 6c) can be compared to an anastomosis or hyphal branching scar, which exhibits a mesh of organic nanofibres, organized as a nest (Fig. 6d) after treatment. Natural nanofibres are often 


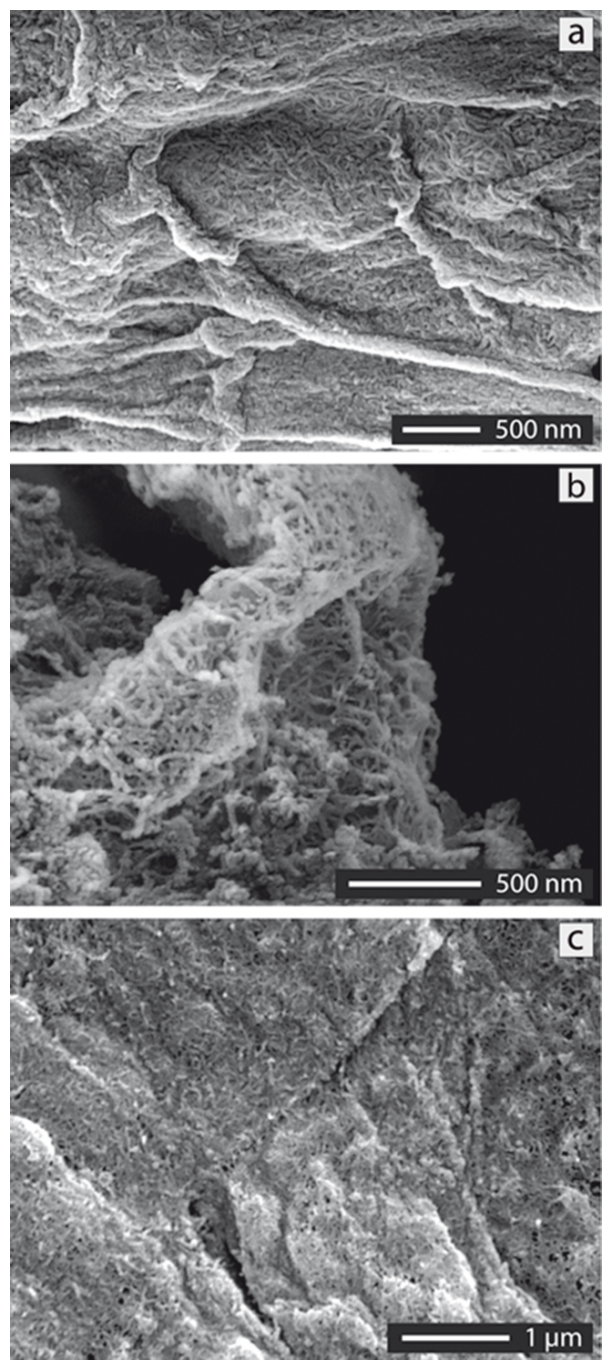

Figure 4. SEM images of mycelia from the three selected species after complete treatment showing a similar final result: organic nanofibres organized into meshes, preserving a hyphal filamentous structure. (a) Petriella sp., (b) Armillaria mellea, (c) Boletus edulis.

observed structured as meshes showing a filament-like organization (Figs. 1b, 2b, c, and 6a-e). The hyphal structure is often preserved after enzymatic digestion. A hyphal shape composed of meshes of organic nanofibres is observed whatever the origin of the sample, natural or produced in laboratory. The organic nanofibres obtained by this method show a mean diameter of $33 \pm 10 \mathrm{~nm}(n=410)$. The mean nanofibre diameter in natural organized meshes is $56 \pm 12 \mathrm{~nm}(n=$ $470)$ and the mean nanofibre diameter in natural randomly organized meshes is $78 \pm 22 \mathrm{~nm}(n=106$; Bindschedler et al., 2010; Fig. 7). The one-way ANOVA followed by the Tukey HSD test shows that all three categories are significantly different from each other with a $p$ value $<0.001$ for all tests. Despite these differences in diameters between nanofibres from natural organized meshes (Figs. 1, 2, and 6a, c, e) and
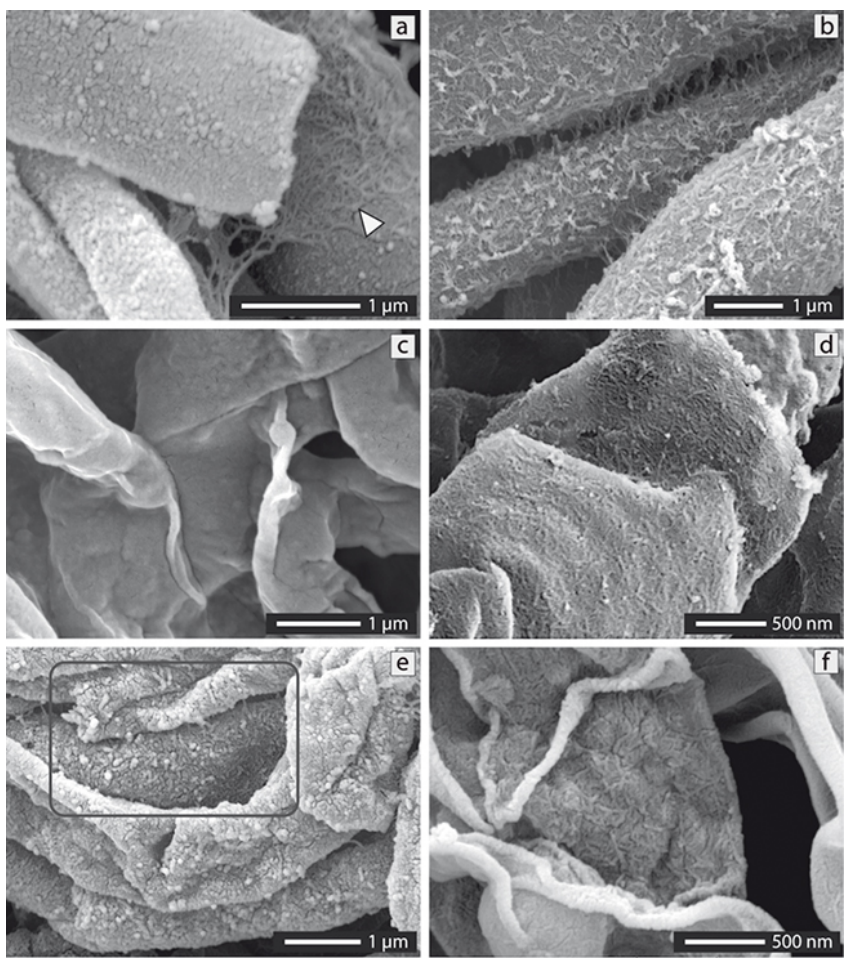

Figure 5. SEM images of Boletus edulis mycelium after each step of treatment. (a) Untreated hyphae showing a granular surface, as well as a mesh of exopolysaccharidic substances between hyphae (white arrow). (b) Hyphae after ultrasonication in ultrapure water, showing a fibro-reticular layer that seems to bind hyphae together. (c) Hyphae after incubation in $5 \% \mathrm{KOH}$ showing a smooth layer. (d) Close-up of the hyphal surface after incubation in $5 \% \mathrm{KOH}$ revealing a mesh of organic nanofibres completely embedded in an amorphous matrix. (e) Hyphae after incubation in the glycolytic mix revealing a fibrillar layer in some areas that seems to be partially embedded in an amorphous matrix (see inside square). (f) Hyphal surface at the end of the treatment show meshes of cell wall nanofibres showing a hyphal structure.

those produced from fungi in vitro (Figs. $4,5 \mathrm{f}$ and $6 \mathrm{~b}, \mathrm{~d}$, f), the similarity of organization between both features remains very convincing.

\subsection{Osmium binding to chitin and $\beta$-glucan}

Energy-dispersive X-ray (EDX) analyses of commercial extracts of chitin and $\beta$-glucan treated with osmium tetroxide have shown that osmium is detected on commercial chitin (Fig. 8a). In contrast, it is not detected on commercial $\beta$ glucan (Fig. 8b).

\section{Discussion}

A fungal origin for nanofibres (either organic or calcitic), recurrently associated with NFC, has already been put forth by Bindschedler et al. (2010), based on observations of natural 

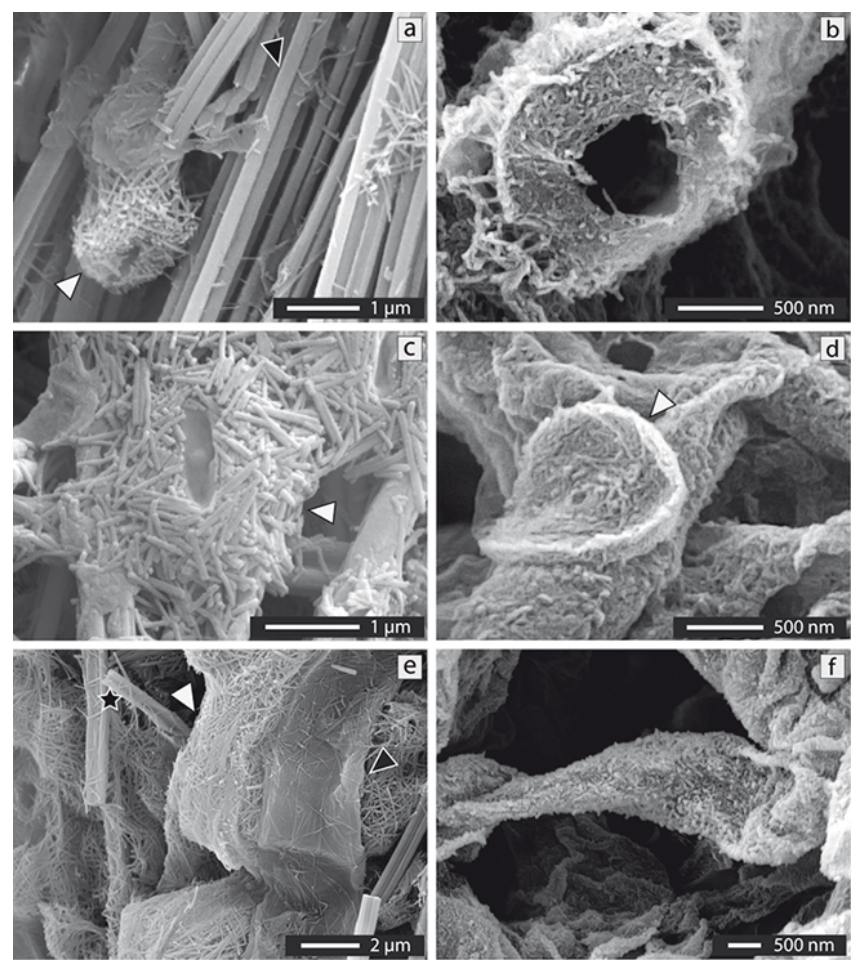

Figure 6. SEM images of both natural and laboratory (posttreated) samples comparing similarities between observed structures. (a) Tubular structure made of organized nanofibres (white arrow) associated to NFC (black arrow). Image from a soil sample of both organic matter and secondary $\mathrm{CaCO}_{3}$ located at the interface between the organic and mineral soil horizons. (b) Armillaria mellea mycelium after complete enzymatic treatment showing a transversal view of a hypha and the relict of the cell wall composed of a mesh of organic nanofibres. (c) Nest-like structure made of nanofibres (white arrow). Image from a sample of both coatings and cotton ball-like NFC developed on scree clast deposits. (d) Petriella $s p$. mycelium after complete enzymatic treatment showing the relict of a septum (either from hyphal anastomosis or branching) composed of a mesh of organic nanofibres (white arrow). (e) Organized meshes of nanofibres displaying a filamentous structure (white arrow) observed together with a decaying fungal hypha showing the same filamentous shape (black arrow). Note the presence of associated NFC (black star). Image from a sample containing decaying organic matter, rhizomorphs, and secondary $\mathrm{CaCO}_{3}$ located at the interface between the organic and mineral soil horizons. (f) Boletus edulis mycelium after complete enzymatic treatment showing meshes of cell wall nanofibres organized into a hyphal filamentous structure.

samples and the recognition of the organic nature of some nanofibres. Organic nanofibres obtained in this study show similar characteristics to those observed in natural samples, particularly regarding their arrangement as organized meshes showing tubular- and filament-like arrangements (Fig. 6). Consequently, this shows that the fungal cell wall is a potential source of organic nanofibres.

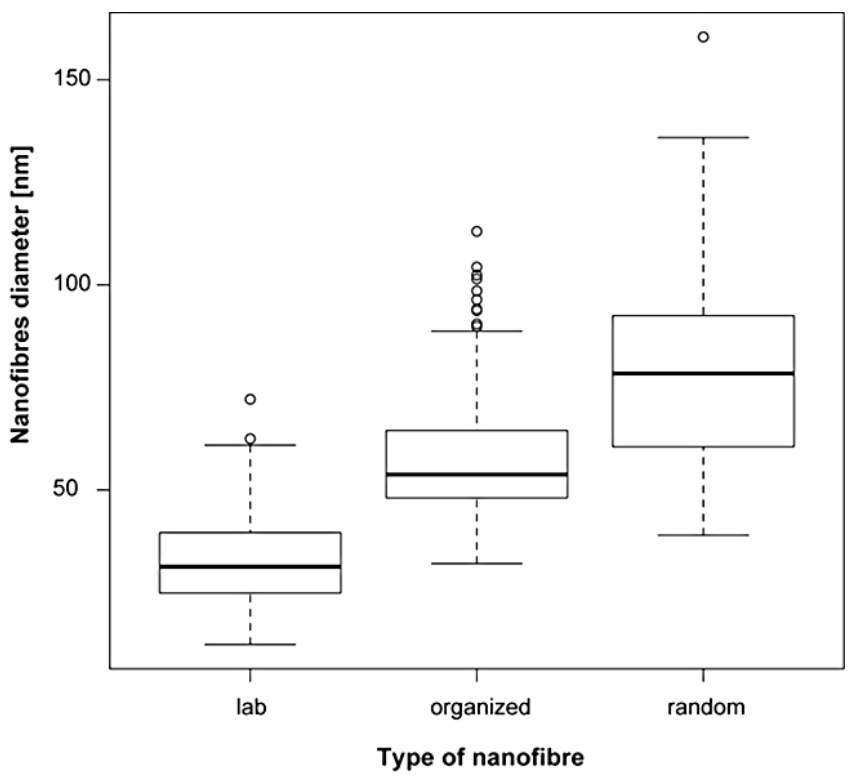

Figure 7. Box plot showing the distribution of diameters with median, standard deviation, maximal and minimal values of the different categories of nanofibres. Data represented for laboratoryobtained nanofibres (lab; $n=410$ ), nanofibres from natural organized nanofibre meshes (organized; $n=470$ ) and nanofibres from natural randomly organized meshes (random; $n=106$ from Bindschedler et al., 2010). Note that all three categories are significantly different with a $p$ value $<0.001$

\subsection{Synthesis of organic nanofibres by a sequential enzymatic digestion of fungal mycelia}

\subsubsection{Processes leading to the conservation of organic nanofibres in pedogenic environments}

In a natural environment, analogous processes of incomplete enzymatic decay can occur, leading to the existence and preservation of organic nanofibres. In soils, studies have demonstrated that chitinase and $\beta$-glucosidase (an enzyme closely related to $\beta$-glucanase) show their optimal activity at acidic pH (Sinsabaugh et al., 2008; Turner, 2010). Laboratory assays with fungal $\beta$-glucanase have shown an optimal activity at $\mathrm{pH}$ around 5 (Chesters and Bull, 1963; Rapp, 1989). Consequently, it is likely that in calcareous environments, where $\mathrm{pH}$ is usually around $7.5-8, \mathrm{pH}$ conditions will decrease or inhibit chitinase and/or $\beta$-glucanase activity, allowing the conservation of chitin and/or $\beta-1,3$ glucan nanofibres. In addition, chitin, as well as $\beta-1,3$ glucan and cellulose, are known as alkali-resistant polysaccharides (Farkaš, 2003). The cross-linking between fibrillar polymers of the cell wall is considered as being the reason for this alkaliinsolubility (Fontaine et al., 1997, 2000). From a purely theoretical point of view, chitin enzymatic hydrolysis is expected to be efficient in the soil environment. But surprisingly, chitin is known to be a recalcitrant polymer of soil organic matter 

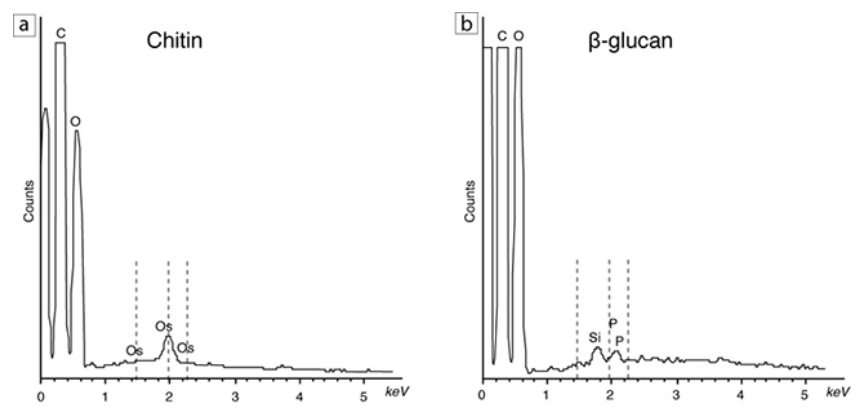

Figure 8. EDS spectra of commercial extracts of chitin (a) and $\beta$ glucan (b). (a) Chitin EDS spectrum shows the presence of carbon $(\mathrm{C})$, oxygen $(\mathrm{O})$ and osmium (Os). (b) $\beta$-glucan EDS spectrum shows the presence of carbon $(\mathrm{C})$, oxygen $(\mathrm{O})$ but no osmium. Note the presence of silicon $(\mathrm{Si})$ and phosphorous $(\mathrm{P})$ due to the preparation procedure for electron microscopy using tetramethylsilane (TMS) and phosphate buffer solutions (PBS). Dotted lines correspond to osmium peaks (M peak at $1.91 \mathrm{keV}$ and two associated peaks).

and does not show a high decay rate (Guggenberger et al., 1999; Ehrlich, 2010; Fan and Guo, 2010). In contrast, Dglucose polymers (such as $\beta-1,3$ glucan nanofibres) are expected to be more readily recyclable polymers (Coleman et al., 2004; Paul, 2007) and $\beta$-1,3-glucan is not known to accumulate in soils. Cross-linking between chitin and $\beta$-1,3glucan in the cell wall could lead to an enhanced preservation of $\beta$-1,3-glucan as a result of low chitin decay rate. However, little information exists on this topic and the outcomes for $\beta$-glucans in pedogenic environments remain presently enigmatic.

\subsubsection{Biochemical nature of organic nanofibres}

Analyses of commercial extracts of chitin and $\beta$-glucans have shown that only chitin has the ability to bind osmium (Fig. 8). As natural non-randomly organized meshes of nanofibres show an osmium signature (Bindschedler et al., 2010), this suggests that organic nanofibres from natural samples that are of fungal origin most probably contain a larger part of chitin compared to $\beta-1,3$ glucan, regarding their osmium signature. In this study, the organic nanofibres produced in the laboratory with selected fungal strains are most likely composed of a mixture of chitin and $\beta-1,3$ glucan nanofibres. While lyticase and laminarinase used to digest amorphous $\beta$-glucans might have digested a part of the fibrous $\beta-1,3$ glucan as well, cross-linking between fibrillar polymers of the cell wall may lead to the removal of covalently linked material in an unpredictable way (Farkaš, 2003). As a result, the organic nanofibres produced in this study might be composed of a varying combination of chitin and $\beta-1,3$ glucan, whereas the organic nanofibres that originate from fungal cell walls in natural samples comprise a greater amount of chitin, based on their osmium signature.

\subsubsection{Hypotheses regarding the mineralization of organic nanofibres}

When chitin and/or $\beta$-1,3 glucan nanofibres are released after the incomplete decay of the fungal cell wall, they may eventually be preserved due to particular prevailing physicochemical conditions in calcareous environments (i.e. $\mathrm{pH}$ above 7.5-8, high carbonate alkalinity, and high $\mathrm{Ca}^{2+}$ concentration). Subsequently, chitin (or $\beta$-1,3-glucan) nanofibres and/or associated acidic proteins can adsorb calcium on their surfaces when exposed to solutions enriched in calcium, and hence act as a calcite nucleation enhancer (Wainwright, 1963; Furlan et al., 1996; Ehrlich, 2010). This process is documented for chitin due to its ubiquity in arthropod cuticles (Ehrlich, 2010). However, $\beta-1,3$ glucan could display the same ability, as this process is documented for cellulose $(\beta$ 1,4 glucan) fibres (Cailleau et al., 2005, 2009a; Cromme et al., 2007), which may be considered as structural analogues of $\beta-1,3$ glucan.

The difference observed in diameter ranges between laboratory and natural nanofibres may be explained by the fact that chitin has the ability to bind cations. In natural environments, cations may be directly adsorbed on sites derived from de-acetylation of amino groups or through associated acidic proteins (Wainwright, 1963; Furlan et al., 1996; Ehrlich, 2010). This adsorption ability might explain why natural nanofibres are smoother and wider than those obtained under laboratory conditions (Fig. 7). Therefore, on the basis of the arguments made above, natural nanofibres might often be coated either with bounded- $\mathrm{Ca}^{2+}$ (ionic bound), $\mathrm{Ca}^{2+}$-bounded macromolecules, or even $\mathrm{CaCO}_{3}$, all three slightly increasing their diameter. Benzerara et al. (2003) observed thin amorphous layers around nanofibres and interpreted them as precursor phases of calcite crystallization. Moreover, in a further study Benzerara et al. (2005) identified that carboxylic groups may be associated with their nanofibres. Carboxylic groups are well known to bind cations such as $\mathrm{Ca}^{2+}$ (Dupraz and Visscher, 2005). Likewise, Cailleau et al. (2009a) suggest a similar adsorption process with cellulose nanofibres in experimental procedures. As a result, an increase of organic nanofibre diameter by adsorption of organic or mineral matter is possible.

Eventually, the precipitation of calcite using chitin (and/or $\beta-1,3$ glucan) nanofibres as nucleation templates may occur if the calcite saturation index in the local microenvironment favours this process. Such a process can be defined as "organomineralization" in the sense defined by Perry et al. (2007) and Dupraz et al. (2009), i.e. all mineral precipitation on an organic matrix that is not genetically controlled. Moreover, it may correspond to a "biologically influenced mineralization" process (Dupraz et al., 2009), defined as the passive mineralization of organic matter. Physicochemical parameters of the environment, influenced either by physicochemical processes or by biological activity (Braissant et al., 2004; Visscher and Stolz, 2005; Gradziński et al., 2012), are 
responsible for creating the conditions leading to $\mathrm{CaCO}_{3} \mathrm{nu}-$ cleation on organic nanofibres. As a result, the process proposed for the genesis of calcitic nanofibres implies the presence of organic matter for the nucleation of $\mathrm{CaCO}_{3}$, but living organisms are not required sensu stricto, except for their metabolic products which can lead to increased calcite saturation level.

\subsection{Critical perspective on alternative hypotheses for the origin of calcitic nanofibres}

As mentioned in Sect. 2, physicochemical processes have been proposed as a possible origin for calcitic nanofibres (Jones and Ng, 1988; Jones and Khale, 1993; Borsato et al., 2000). This hypothesis seems unlikely mainly because of the peculiar thread-like habitus of nanofibres. Calcitic nanofibres are believed to be monocrystalline in nature (Cailleau et al., 2009a) with their growth axis parallel to the calcite $c$ axis (Borsato et al., 2000), this latter point being still under discussion. Moreover, they are low-Mg calcite in nature (Loisy et al., 1999; Borsato et al., 2000). The habitus of a physicochemically precipitated calcite crystal under no constraint (either by ion poisoning or by the presence of adsorbed organic matter) should have some rhombohedral patterns if following crystallographic rules (Buckley, 1951), which is evidently not the case with nanofibres. One way to have an elongated crystal shape would be through a growth constraint by ion poisoning (e.g. $\mathrm{Mg}^{2+}$ ), however this is not consistent with their low-Mg calcitic nature. Stabilization of ACC phases by silica coatings (Kellermeier et al., 2012) seems also unlikely as X-Ray Diffraction (XRD) usually detects only low-Mg calcite phases and no ACC (e.g. Bindschedler et al., 2010). Finally, a VLS growth mechanism, as proposed by Borsato et al. (2000) would explain the thread-like habitus, but is inconsistent with the observation of non-random organized meshes (Figs. 1, 2 and 6a, c, e). Thus, a physicochemical process alone is unlikely to explain the existence of highly organized objects composed of nanofibres, such as the one observed in several studies (Klappa, 1979; their Fig. 3b; Ould Mohamed and Bruand, 1994; their Fig. 4e; Borsato et al., 2000; their Fig. 5; Richter et al., 2008; their Fig. 3; Cailleau et al., 2009a; their Fig. 1). For this reason, the presence of an organic template directing the growth of the nanofibre seems more suitable to explain the peculiar habitus of nanofibres. Organic matter is known to induce great variations from the theoretical crystal habitus (Buckley, 1951; Simkiss and Wilbur, 1989; Mann, 2000). Moreover, it elegantly explains the non-random spatial organization patterns of nanofibres.

Another hypothesis for the origin of nanofibres involves the biomineralization of rod-shaped nano-sized bacteria (Phillips and Self, 1987; Ould Mohamed and Bruand, 1994; Verrecchia and Verrecchia, 1994; Gradziński et al., 1997; Loisy et al. 1999). Nevertheless, this hypothesis seems unlikely as well. As already explained in the Sect. 2, a controversy is still ongoing regarding the existence of nanobac- teria (Folk, 1993; Kirkland et al. 1999; Folk and Lynch, 2001; Schieber and Arnott, 2003; Martel and Young, 2008; Young et al., 2009; Pacton and Gorin, 2011). Maniloff et al. (1997) have defined that the lowest diameter for a cell to be viable must be $0.005 \mu \mathrm{m}^{3}$. According to this assumption, Kieft (2000) states that nanobacteria defined by Folk (1993) would have no space for a cytoplasm. Even if the lower size limit for a living cell has still to be defined with precision, it is quite unlikely that they would have a diameter lower than $0.2 \mu \mathrm{m}$. This theoretical size limitation arises from solution chemistry. Indeed, solute concentration within cells is often at the level of micromoles $(\mu \mathrm{M})$ and consequently a very small biovolume would be too limited to allow the presence of at least one molecule (Kieft, 2000). Accordingly, regarding the above points, natural nanofibres exhibit dimensions under the reasonable limit for a viable cell. With an average diameter of $80 \mathrm{~nm}$ and an average length of $500 \mathrm{~nm}$, the total biovolume is $0.0025 \mu \mathrm{m}^{3}$, which is two times smaller than the limit of $0.005 \mu \mathrm{m}^{3}$ defined by Maniloff et al. (1997). As a consequence, only the nanofibres with diameters above $200 \mathrm{~nm}$ could possibly be nanobacteria. Then again, the presence of bacteria at such high densities (as represented by the presence of dense meshes of intertwined meshes) in oligotrophic environments such as caves and deep soils remains odd. Therefore, the hypothesis of the mineralization of nanobacteria seems rather unlikely, although it cannot be completely occluded based on present-day knowledge.

\subsection{Importance of nanofibres organomineralization}

It must be pointed out that the same organomineralization process proposed for the origin of calcitic nanofibres in this paper has been proposed for cellulose nanofibres from plant cell by Cailleau et al. (2009a) with synthetic cellulose or natural cellulose fibres in wood structures (Cailleau et al., 2005). Plant cell walls are well known to possess a fibrillar layer made of a dense mesh of fibrous cellulose and hemicellulose (Paul, 2007), whereas fungi possess a cell wall with a layer of fibrous chitin and $\beta-1,3$ glucan (Ruiz-Herrera, 1992). Interestingly, cellulose and chitin are known as the two most abundant natural polymers on Earth (Furlan et al., 1996; Ehrlich, 2010) and both exhibit poor complete degradation in natural environments. In order to complete their full mineralization, the action of a consortium of organisms together with particular physicochemical conditions is often necessary (Paul, 2007). Their potential preservation in the environment under certain conditions makes them available to further participate in other soil solution mediated processes, such as acting as a template for the nucleation of secondary minerals. Indeed, both cellulose and chitin are known to be efficient templates for calcite nucleation (Manoli et al., 1997; Dalas et al., 2000; Giraud-Guille et al., 2004; Cailleau et al., 2005, 2009a; Cromme et al., 2007; Ehrlich, 2010). Therefore, both organopolymers can be considered as important templates for organomineralization processes. This does not 
rule out the fungal origin of organic nanofibres pointed out in the present study. But it emphasizes organomineralization processes as an important, yet underestimated, aspect of the coupled $\mathrm{Ca}-\mathrm{C}$ biogeochemical cycle.

The fact that organic matter can enhance or govern crystallization is a well-known feature of biomineralization theories (Simkiss and Wilbur, 1989; Berman et al., 1993; Dupraz et al., 2009). Klappa (1979) has already mentioned the possibility that nanofibres could be the remains of cell walls, either fungal or plant; this author mentions "hyphantic threads" as being the result of "partially decayed organic filaments". Therefore, the involvement of an organic template in the genesis of calcitic nanofibres seems realistic for all the reasons mentioned above. This hypothesis has the advantage of explaining, in a logical way, the existence of tube-like organized structures in natural samples (Figs. 1b, c). Moreover, in some cases, cross-linking between chitin and $\beta-1,3$ glucan might lead to an enhanced preservation of these structures.

\section{Conclusions}

The origin of nanofibres remains enigmatic, mainly because of the limits of methodology. Indeed, the lack of routine methods to accurately analyse organo-mineral structures at the submicrometric scale still hinders a clear and unquestionable answer regarding their origin. Nevertheless, regarding the three main theories currently discussed, i.e. physicochemical processes, biomineralization of rod-shaped nanosized bacteria, and nucleation mediated by organic templates, the latter seems to be the most realistic considering our present knowledge on the nature of calcitic nanofibres and the results discussed in the study presented in this paper. Indeed, the sequential digestion of the fungal cell wall using enzymes has shown thrilling converging morphologies between laboratory and natural meshes of organic nanofibres, which are in agreement with biochemical constraints of organic matter breakdown in natural environments. This study emphasizes as well the role of natural polymers as templates for the precipitation of minerals. The focus has been purposefully put on a fungal origin for organic nanofibres, essentially those associated with NFC. However, this does not exclude other sources for organic nanofibres. Indeed, other natural polymers display a nanofibrous shape, e.g. cellulose, which is known to act as a template for $\mathrm{CaCO}_{3}$ nucleation (Cailleau et al., 2005, 2009a). As chitin and cellulose are considered to be the two most widespread natural polymers on Earth (Furlan et al., 1996; Ehrlich, 2010), this process may have a great, yet underestimated, influence on both $\mathrm{Ca}$ and $\mathrm{C}$ biogeochemical cycles.

Acknowledgements. The authors would like to thank: André Villard and Michèle Vlimant for their technical assistance during sample preparation for TEM purposes; Massoud Dadras, Vladislav Spassov and Mireille Leboeuf from CSEM and Pierre Vonlanthen at UNIL for their assistance in using electron microscopy; The Swiss Federal Research Institute WSL, CH-8903 Birmensdorf, for providing the Boletus edulis strain (23.01); and Karin Verrecchia for improving the English of the paper. This work was supported by the Swiss National Science Foundation, grant nos. FN 646 205320-109497/1 and FN 205320-122171.

Edited by: T. Treude

\section{References}

Alonso-Zarza, A. M. and Jones, B.: Root calcrete formation on Quaternary karstic surfaces of Grand Cayman, Geol. Acta, 5, 77-88, 2007.

Anand, R. R., Phang, C., Wildman, J. E., and Lintern, M. J.: Genesis of some calcretes in the southern Yilgarn Craton, Western Australia: Implications for mineral exploration, Aust. J. Earth Sci., 44, 87-103, 1997.

Aronson, J. M. and Preston, R. D.: An electron microscopic and Xray analysis of the walls of selected lower phycomycetes, P. Roy. Soc. Lond. B Bio., 152, 346-352, 1960.

Bajnóczi, B. and Kovács-Kis, V.: Origin of pedogenic needle-fiber calcite revealed by micromorphology and stable isotope composition - A case study of a Quaternary paleosol from Hungary, Chem. Erde-Geochem., 66, 203-212, 2006.

Banerjee, S. and Joshi, S. R.: Insights into cave architecture and the role of bacterial biofilm, P. Natl. A. Sci. India B, 83, 277-290, 2013.

Bartnicki-García, S.: Cell wall chemistry, morphogenesis and taxonomy of fungi, Annu. Rev. Microbiol., 22, 87-108, 1968.

Benzerara, K., Menguy, N., Guyot, F., Dominici, C., and Gillet, P.: Nanobacteria-like calcite single crystals at the surface of the Tataouine meteorite, P. Natl. Acad. Sci. USA, 100, 7438-7442, 2003.

Benzerara, K., Menguy, N., Guyot, F., Vanni, C., and Gillet, P.: TEM study of a silicate-carbonate-microbe interface prepared by focused ion beam milling, Geochim. Cosmoschim. Ac., 69, 1413-1422, 2005.

Berman, A., Hanson, J., Leiserowitz, L., Koetzle, T. F., Weiner, S., and Addadi, L.: Biological-control of crystal texture - A widespread strategy for adapting crystal properties to function, Science, 259, 776-779, 1993.

Bindschedler, S., Millière, L., Cailleau, G., Job, D., and Verrecchia, E. P.: Calcitic nanofibres in soils and caves: A putative fungal contribution to carbonatogenesis, in: Tufas and Speleothems Unravelling the Microbial and physical controls, edited by: Pedley, H. M. and Rogerson, M., Geol. Soc. SP., London, 225-238, 2010.

Bindschedler, S., Millière, L., Cailleau, G., Job, D., and Verrecchia, E. P.: An ultrastructural approach to analogies between fungal structures and needle fibre calcite, Geomicrobiol J, 29, 301-313, 2012.

Blyth, A. J. and Frisia, S.: Molecular evidence for bacterial mediation of calcite formation in cold high-altitude caves, Geomicrobiol J., 25, 101-111, 2008.

Boquet, E., Bordonat, A., and Ramos Cormenzana, A.: Production of calcite crystals by soil bacteria is a general phenomenon, Nature, 246, 527-528, 1973. 
Borsato, A., Frisia, S., Jones, B., and Van der Borg, K.: Calcite moonmilk: Crystal morphology and environment of formation in caves in the Italian Alps, J. Sediment. Res., 70, 1171-1182, 2000.

Bowman, S. M. and Free, S. J.: The structure and synthesis of the fungal cell wall, BioEssays, 28, 799-808, 2006.

Braissant, O., Cailleau, G., Aragno, M., and Verrecchia, E. P.: Biologically induced mineralization in the tree Milicia excelsa (Moraceae): its causes and consequences to the environment, Geobiology, 2, 59-66, 2004.

Braissant, O., Decho, A. W., Przekop, K. M., Gallagher, K. L., Glunk, C., Dupraz, C., and Visscher, P. T.: Characteristics and turnover of exopolymeric substances in a hypersaline microbial mat, FEMS Microbiol. Ecol., 67, 293-307, 2009.

Buckley, H. E.: Crystal growth, Wiley and Sons/Chapman and Hall, New York/London, 571 pp., 1951.

Burnett, J. H.: Aspects of the structure and growth of hyphal walls, in: Fungal walls and hyphal growth, edited by: Burnett, J. H., and Trinci, A. P. J., British Mycological Society, Cambridge University Press, Cambridge, 1-25, 1979.

Cailleau, G., Braissant, O., Dupraz, C., Aragno, M., and Verrecchia, E. P.: Biologically induced accumulations of $\mathrm{CaCO}_{3}$ in orthox soils of Biga, Ivory Coast, Catena, 59, 1-17, 2005.

Cailleau, G., Dadras, M., Abolhassani-Dadras, S., Braissant, O., and Verrecchia, E. P.: Evidence for an organic origin of pedogenic calcitic nanofibres, J Cryst Growth, 311, 2490-2495, 2009a.

Cailleau, G., Verrecchia, E. P., Braissant, O., and Emmanuel, L.: The biogenic origin of needle fibre calcite, Sedimentology, 56, 1858-1875, 2009b.

Callot, G., Guyon, A., and Mousain, D.: Relation between calcite needles and fungal hyphae in the soil, Agronomie, 5, 209-216, 1985a.

Callot, G., Mousain, D., and Plassard, C.: Concentration of calciumcarbonate on the walls of fungal hyphae, Agronomie, 5, 143-150, $1985 b$.

Cañaveras, J. C., Hoyos, M., Sanchez-Moral, S., Sanz-Rubio, E., Bedoya, J., Soler, V., Groth, I., Schumann, P., Laiz, L., Gonzalez, I., and Saiz-Jimenez, C.: Microbial communities associated with hydromagnesite and needle-fiber aragonite deposits in a karstic cave (Altamira, northern Spain), Geomicrobiol. J., 16, 9-25, 1999.

Cañaveras, J., Sanchez-Moral, S., Soler, V., and Saiz-Jimenez, C.: Microorganisms and microbially induced fabrics in cave walls, Geomicrobiol. J., 18, 223-240, 2001.

Cañaveras, J. C., Cuezva, S., Sanchez-Moral, S., Lario, J., Laiz, L., Gonzalez, J. M., and Saiz-Jimenez, C.: On the origin of fiber calcite in moonmilk deposits, Naturwissenschaften, 93, 27-32, 2006

Carlile, M. J., Watkinson, S. C., and Gooday, G. W.: The Fungi, Elsevier academic press, 588 pp., 2001.

Chesters, C. G. and Bull, A. T.: Enzymic degradation of laminarin, 3. Some effects of temperature, $\mathrm{pH}$ and various chemical reagents on fungal laminarinases, Biochem J, 86, 38-46, 1963.

Coleman, D. C., Crossley Jr., D. A., and Hendrix, P. F.: Fundamentals of soil ecology, 2nd Edn., Elsevier Academic Press, 386 pp., 2004.

Cromme, P., Zollfrank, C., Muller, L., Muller, F. A., and Greil, P.: Biomimetic mineralisation of apatites on $\mathrm{Ca}^{2+}$ activated cellulose templates, Mat. Sci. Eng. C-Bio. S., 27, 1-7, 2007.
Curry, M. D., Boston, P. J., Spilde, M. N., Baichtal, J. F., and Campbell, A. R.: Cottonballs, a unique subaqueous moonmilk, and abundant subaerial moonmilk in Cataract Cave, Tongass National Forest, Alaska, Int. J. Speleol., 38, 111-128, 2009.

Dalas, E., Klepetsanis, P. G., and Koutsoukos, P. G.: Calcium carbonate deposition on cellulose, J. Colloid. Interf. Sci., 224, 5662,2000

Dey, S., Basu Baul, T. S., Roy, B., and Dey, D.: A new rapid method of air-drying for scanning electron microscopy using tetramethylsilane, J. Microsc., 156, 259-261, 1989.

Dubroeucq, D., Geisseirt, D., and Roger, P.: Pine Root-induced petrocalcic horizons in volcanis ash soils of the Mexican altiplano, Memorias del III Simposio Internacional sobre Suelos volcanicos endurecidos (Quito), 1996.

Dupraz, C. and Visscher, P.T.: Microbial lithification in marine stromatolites and hypersaline mats, Trends Microbiol, 13, 429-438, 2005.

Dupraz, C., Reid, R. P., Braissant, O., Decho, A. W., Norman, R. S., and Visscher, P. T.: Processes of carbonate precipitation in modern microbial mats, Earth-Sci. Rev., 96, 141-162, 2009.

Ehrlich, H.: Chitin and collagen as universal and alternative templates in biomineralization, Int. Geol. Rev., 52, 661-699, 2010.

Fan, P. P. and Guo, D. L.: Slow decomposition of lower order roots: a key mechanism of root carbon and nutrient retention in the soil, Oecologia, 163, 509-515, 2010.

Farkaš, V.: Biosynthesis of cell-walls of fungi, Microbiol. Rev., 43, 117-144, 1979.

Farkaš, V.: Structure and biosynthesis of fungal cell walls: Methodological approaches, Folia. Microbiol., 48, 469-478, 2003.

Folk, R. L.: SEM imaging of bacteria and nannobacteria in carbonate sediments and rocks, J. Sediment. Petrol., 63, 990-999, 1993.

Folk, R. L. and Lynch, F. L.: Organic matter, putative nannobacteria and the formation of ooids and hardgrounds, Sedimentology, 48, 215-229, 2001.

Fontaine, T., Mouyna, I., Hartland, R. P., Paris, S., and Latgé, J. P.: From the surface to the inner layer of the fungal cell wall, Biochem. Soc. T., 25, 194-199, 1997.

Fontaine, T., Simenel, C., Dubreucq, G., Adam, O., Delepierre, M., Lemoine, J., Vorgias, C. E., Diaquin, M., and Latgé, J.-P.: Molecular organization of the alkali-insoluble fraction of Aspergillus fumigatus cell wall, J. Biol. Chem., 275, 27594-27607, 2000.

Furlan, L., deFavere, V. T., and Laranjeira, M. C. M.: Adsorption of calcium ions by graft copolymer of acrylic acid on biopolymer chitin, Polymer, 37, 843-846, 1996.

Gillet, P., Barrat, J. A., Heulin, Th., Achouak, W., Lesourd, M., Guyot, F., and Benzerara, K.: Bacteria in the Tatahouine meteorite: nanometric-scale life in rocks, Earth Planet. Sc. Lett., 175, 161-167, 2000.

Giraud-Guille, M. M., Belamie, E., and Mosser, G.: Organic and mineral networks in carapaces, bones and biomimetic materials, C. R. Palevol, 3, 503-513, 2004.

Gobat, J.-M., Aragno, M., and Matthey, W.: Le sol vivant, Presses polytechniques et universitaires romandes, 568 pp., 2003.

Gradziński, M.: Microbial agents of moonmilk calcification, Proceedings of the 12th International Congress of Speleology, La Chaux-de-Fonds, Switzerland, 1, 275-278, 1997.

Gradziński, M., Chmiel, M. J., and Motyka, J.: Formation of calcite by chemolithoautotrophic bacteria - a new hypothesis, based on 
microcrystalline cave pisoids, Ann. Soc. Geol Pol., 82, 361-369, 2012.

Guggenberger, G., Frey, S. D., Six, J., Paustian, K., and Elliott, E. T.: Bacterial and fungal cell-wall residues in conventional and no-tillage agroecosystems, Soil. Sci. Soc. Am. J., 63, 1188-1198, 1999.

Homeijer, S. J., Olszta, M. J., Barrett, R. A., and Gower, L. B.: Growth of nanofibrous barium carbonate on calcium carbonate seeds, J. Cryst. Growth, 310, 2938-2945, 2008.

Hunsley, D. and Burnett, J. H.: Ultrastructural architecture of walls of some hyphal fungi, J. Gen. Microbiol., 62, 203-218, 1970.

IUSS Working Group WRB: World references base for resources 2006, 2nd ed, Rome, 2006.

Iwanoff, L. L.: Ein wasserhaltiges Calcium Carbonat aussen Umbegung von Nowo-Alexandria (guv. Lublin), Annalen der Geologie und Mineralogie der Russland, 8, 23-25, 1906.

Jeong, G. Y. and Chun, Y. S.: Nanofiber calcite in Asian dust and its atmospheric roles, Geophys. Res. Lett., 33, L24802, doi:10.1029/2006GL028280, 2006.

Jones, B. and Khale, C. F.: Morphology, relationship, and origin of fiber and dendrite calcite crystals, J. Sediment. Petrol., 63, 10181031, 1993.

Jones, B. and Ng, K. C.: The structure and diagenesis of rhizoliths from Cayman Brac, British-West-Indies, J. Sediment. Petrol., 58, 457-467, 1988

Kellermeier, M., Melero-García, E., Kunz, W., and García-Ruiz, J. M.: The ability of silica to induce biomimetic crystallization of calcium carbonate, in: Kinetics and thermodynamics of multistep nucleation and self-assembly in nanoscale materials: Advances in chemical physics, edited by: Nicolis, G., and Maes, D., John Wiley \& Sons, Inc., Hoboken, NJ, USA, 2012.

Khormali, F., Abtahi, A., and Stoops, G.: Micromorphology of calcitic features in highly calcareous soils of Fars Province, Southern Iran, Geoderma, 132, 31-46, 2006.

Kieft, T. L.: Size matters: dwarf cells in soil and subsurface terrestrial environments, in: Nonculturable microorganisms in the environment, edited by: Colwell, R. R., and Grimes, D. J., ASM Press, Washington, DC, 19-46, 2000.

Kirkland, B. L., Lynch, F. L., Rahnis, M. A., Folk, R. L., Molineux, I. J., and McLean, R. J. C.: Alternative origins for nannobacterialike objects in calcite, Geology, 27, 347-350, 1999.

Klappa, C.: Calcified filaments in Quaternary calcretes: organomineral interactions in the subaerial vadose environment, J. Sediment. Petrol., 49, 955-968, 1979.

Latgé, J.-P.: The cell wall: a carbohydrate armour for the fungal cell, Mol Microbiol, 66, 279-290, 2007.

Loisy, C., Verrecchia, E. P., and Dufour, P.: Microbial origin for pedogenic micrite associated with a carbonate paleosol (Champagne, France), Sediment. Geol., 126, 193-204, 1999.

Lowenstam, H. A. and Weiner, S.: On biomineralization, Oxford University Press, New York, 1989.

Maniloff, J., Nealson, K. H., Psenner, R., Loferer, M., and Folk, R. L.: Nannobacteria: Size limits and evidence, Science, 276, 17761776, 1997.

Mann, S.: The chemistry of form, Angew Chem-Int Edit, 39, 33933406, 2000.

Manoli, F., Koutsopoulos, S., and Dalas, E.: Crystallization of calcite on chitin, J. Cryst. Growth, 182, 116-124, 1997.
Martel, J. and Young, J. D.-E.: Purpoted nanobacteria in human blood as calcium carbonate nanoparticles, P. Natl. Acad. Sci. USA, 105, 5549-5554, 2008.

Marx, D. H. and Bryan, W. C.: Influence of ectimycorrhizae on survival and growth of aseptic seedlings of loblolly pine at high temperature, Forest Sci., 17, 37-41, 1971.

Millière, L., Hasinger, O., Bindschedler, S., Cailleau, G., Spangenberg, J. E., and Verrecchia, E. P.: Stable carbon and oxygen isotope signatures of pedogenic needle fibre calcite, Geoderma, 161, 74-87, 2011a.

Millière, L., Spangenberg, J. E., Bindschedler, S., Cailleau, G., and Verrecchia, E. P.: Reliability of stable carbon and oxygen isotope compositions of pedogenic needle fibre calcite as environmental indicators: examples from Western Europe, Isot. Environ. Healt S., 47, 341-358, 2011b.

Mügge, O.: über die Lublinit genannte, augeblich neue Modification des kohlensauren Kalkes, Zbl. Mineral. Geol. Pal., 1914, 673-675, 1914.

Newman, B. D., Norman, D. I., Gundimeda, M., and Levy, S. S.: Understanding the genesis of nonmarine calcite deposits through quadrupole mass spectrometric analysis of fluid inclusion gases, Chem. Geol., 132, 205-213, 1996.

Olszta, M. J., Gajjeraman, S., Kaufman, M., and Gower, L. B.: Nanofibrous calcite synthesized via a solution-precursor-solid mechanism, Chem. Mater., 16, 2355-2362, 2004.

Ould Mohamed, S. and Bruand, A.: Morphology and origin of secondary calcite in soils from Beauce, France, IX International Working Meeting on Soil Micromorphology, Townsville, Australia, 1994.

Pacton, M. and Gorin, G. G.: Nan(n)obacteria, in: Encyclopedia of Geobiology, edited by: Reitner, J., and Thiel, V., Springer, Dordrecht, The Netherlands, 677-680, 2011.

Paul, E. A.: Soil microbiology, ecology and biochemistry, edited by: Paul, E. A., Academic Press, San Diego, 532 pp., 2007.

Pearson, V. K., Kearsley, A. T., and Sephton, M. A.: The in-situ detection of organic material in extraterrestrial samples, Microsc. Anal., 5-8, 2004.

Perry, R. S., McLoughlin, N., Lynne, B. Y., Sephton, M. A., Oliver, J. D., Perry, C. C., Campbell, K., Engel, M. H., Farmer, J. D., Brasier, M. D., and Staley, J. T.: Defining biominerals and organominerals: Direct and indirect indicators of life, Sediment. Geol., 201, 157-179, 2007.

Phillips, S. E. and Self, P. G.: Morphology, crystallography and origin of needle-fiber calcite in Quaternary pedogenic calcretes of South-Australia, Aust. J. Soil. Res., 25, 429-444, 1987.

Phillips, S. E., Milnes, A. R., and Foster, R. C.: Calcified filaments - an example of biological influences in the formation of calcrete in South-Australia, Aust. J. Soil. Res., 25, 405-428, 1987.

R Development Core Team: R: A language and environment for statistical computing. R Foundation for Statistical Computing, Vienna, 2010.

Rapp, P.: 1,3-beta-glucanase, 1,6-beta-glucanase and betaglucosidase activities of Sclerotium glucanicum - Synthesis and properties, J. Gen. Microbiol., 135, 2847-2858, 1989.

Richter, D. K., Immenhauser, A., and Neuser, R. D.: Electron backscatter diffraction documents randomly orientated c-axes in moonmilk calcite fibres: evidence for biologically induced precipitation, Sedimentology, 55, 487-497, 2008. 
Ruiz-Herrera, J.: Fungal cell wall: structure, synthesis and assembly, CRC Press, Boca Raton, Florida, 248 pp., 1992.

Schieber, J. and Arnott, H. J.: Nannobacteria as a by-product of enzyme-driven tissue decay, Geology, 31, 717-720, 2003.

Shankar, N. and Achyuthan, H.: Genesis of calcic and petrocalcic horizons from Coimbatore, Tamil Nadu: Micromorphology and geochemical studies, Quatern. Int., 175, 140-154, 2007.

Simkiss, K. and Wilbur, K. M.: Biomineralization, cell biology and mineral deposition, Academic Press Inc., San Diego, 1989.

Sinsabaugh, R. L., Lauber, C. L., Weintraub, M. N., Ahmed, B., Allison, S. D., Crenshaw, C., Contosta, A. R., Cusack, D., Frey, S., Gallo, M. E., Gartner, T. B., Hobbie, S. E., Holland, K., Keeler, B. L., Powers, J. S., Stursova, M., Takacs-Vesbach, C., Waldrop, M. P., Wallenstein, M. D., Zak, D. R., and Zeglin, L. H.: Stoichiometry of soil enzyme activity at global scale, Ecol. Lett., 11, 1252-1264, 2008.

Stoops, G. J.: On the nature of "lublinite" from Hollanta (Turkey), Am Mineral, 61, p. 172, 1976.

Strong, G. E., Giles, J. R. A., and Wright, V. P.: A Holocene calcrete from North-Yorkshire, England - Implications for interpreting paleoclimates using calcretes, Sedimentology, 39, 333-347, 1992.

Turner, B. L.: Variation in $\mathrm{pH}$ optima of hydrolytic enzyme activities in tropical Rain Forest soils, Appl Environ Microb, 76, 64856493, 2010.

Turner, B. R. and Makhlouf, I.: Quaternary sandstones, northeast Jordan: Age, depositional environments and climatic implications, Palaeogeogr. Palaeocl., 229, 230-250, 2005.

Vergès, V., Madon, M., Bruand, A., and Bocquier, G.: Morphologie et cristallogenèse de microcristaux supergènes de calcite en aiguilles, Bulletin de Minéralogie, 105, 351-356, 1982.
Verrecchia, E. P. and Verrecchia, K. E.: Needle-fiber calcite: A critical review and a proposed classification, J Sediment Res A, 64, 650-664, 1994.

Verrecchia, E. P. and Dumont, J. L.: A biogeochemical model for chalk alteration by fungi in semiarid environments, Biogeochemistry, 35, 447-470, 1996.

Visscher, P. T. and Stolz, J. F.: Microbial mats as bioreactors: populations, processes, and products, Palaeogeogr Palaeocl, 219, 87$100,2005$.

Wainwright, S. A.: Skeletal organization in coral, Pocillopora damicornis, Q. J. Microsc. Sci., 104, 169-183, 1963.

Webster, J. and Weber, R.: Introduction to Fungi, Cambridge University Press, 841 pp., 2007.

Weiner, S. and Dove, P. M.: An overview of biomineralization processes and the problem of the vital effect, in: Biomineralization, edited by: Dove, P. M., DeYoreo, J. J., and Weiner, S., Rev. Mineral. Geochem., 1-29, 2003.

Wright, V. P.: The Significance of Needle-Fiber Calcite in a lower Carboniferous palaeosol, Geol. J., 19, 23-32, 1984.

Wright, V. P.: The role of fungal biomineralization in the formation of early Carboniferous soil fabrics, Sedimentology, 33, 831-838, 1986.

Young, J. D, Martel, J., Young, L., Wu, C.-Y., Young., A, and Young, D.: Putative nanobacteria represent physiological remnants and culture by products of normal calcium homeostasis, PLoS ONE, 4, e4417, doi:10.1371/journal.pone.0004417, 2009.

Zhou, J. and Chafetz, H. S.: Biogenic caliches in Texas: the role of organisms and effect of climate, Sediment. Geol., 222, 207-225, 2009.

Zhu, J. H., Song, J. M., Yu, S. H., Zhang, W. Q., and Shi, J. X.: Mineralization for micropatterned growth of carbonate nanofibers, Crystengcomm, 11, 539-541, 2009. 